\title{
A EXCLUSÃO DO HERDEIRO POR INDIGNIDADE: NECESSIDADE DE UMA SENTENÇA PENAL
}

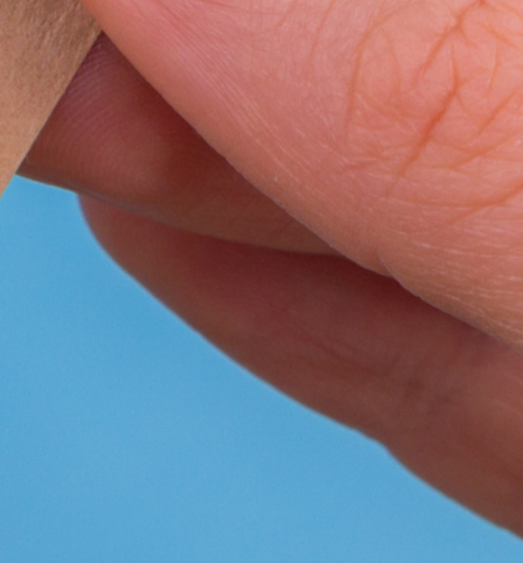


LAÍS RODRIGUES AMARO

A EXCLUSÃO DO HERDEIRO POR INDIGNIDADE: NECESSIDADE DE UMA SENTENÇA PENAL

$1^{\underline{a}}$ ed.

Piracanjuba-GO

Editora Conhecimento Livre

Piracanjuba-GO 
$1^{\mathrm{a}} \mathrm{ed}$

\section{Dados Internacionais de Catalogação na Publicação (CIP)}

\section{AMARO, LAIIS RODRIGUES \\ A485A A EXCLUS ÃO DO HERDEIRO POR INDIGNIDADE: NECESSIDADE DE UMA}

SENTENÉERQPERKGUES AMARO. - Piracanjuba-GO

Editora Conhecimento Livre, 2022

$56 \mathrm{f.:}$ il

DOI: $10.37423 / 2022$. edcl 419

ISBN: 978-65-5367-042-6

Modo de acesso: World Wide Web

Incluir Bibliografia

1. sucessão 2. indignidada 3. exclusão I. AMARO, LAÍS RODRIGUES II. Título 


\title{
EDITORA CONHECIMENTO LIVRE
}

\section{Corpo Editorial}

\author{
Dr. João Luís Ribeiro Ulhôa \\ Dra. Eyde Cristianne Saraiva-Bonatto \\ MSc. Frederico Celestino Barbosa \\ MSc. Carlos Eduardo de Oliveira Gontijo \\ MSc. Plínio Ferreira Pires
}


A EXCLUSÃO DO HERDEIRO POR INDIGNIDADE: NECESSIDADE DE UMA SENTENÇA PENAL

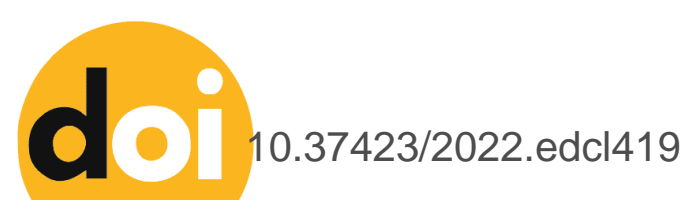

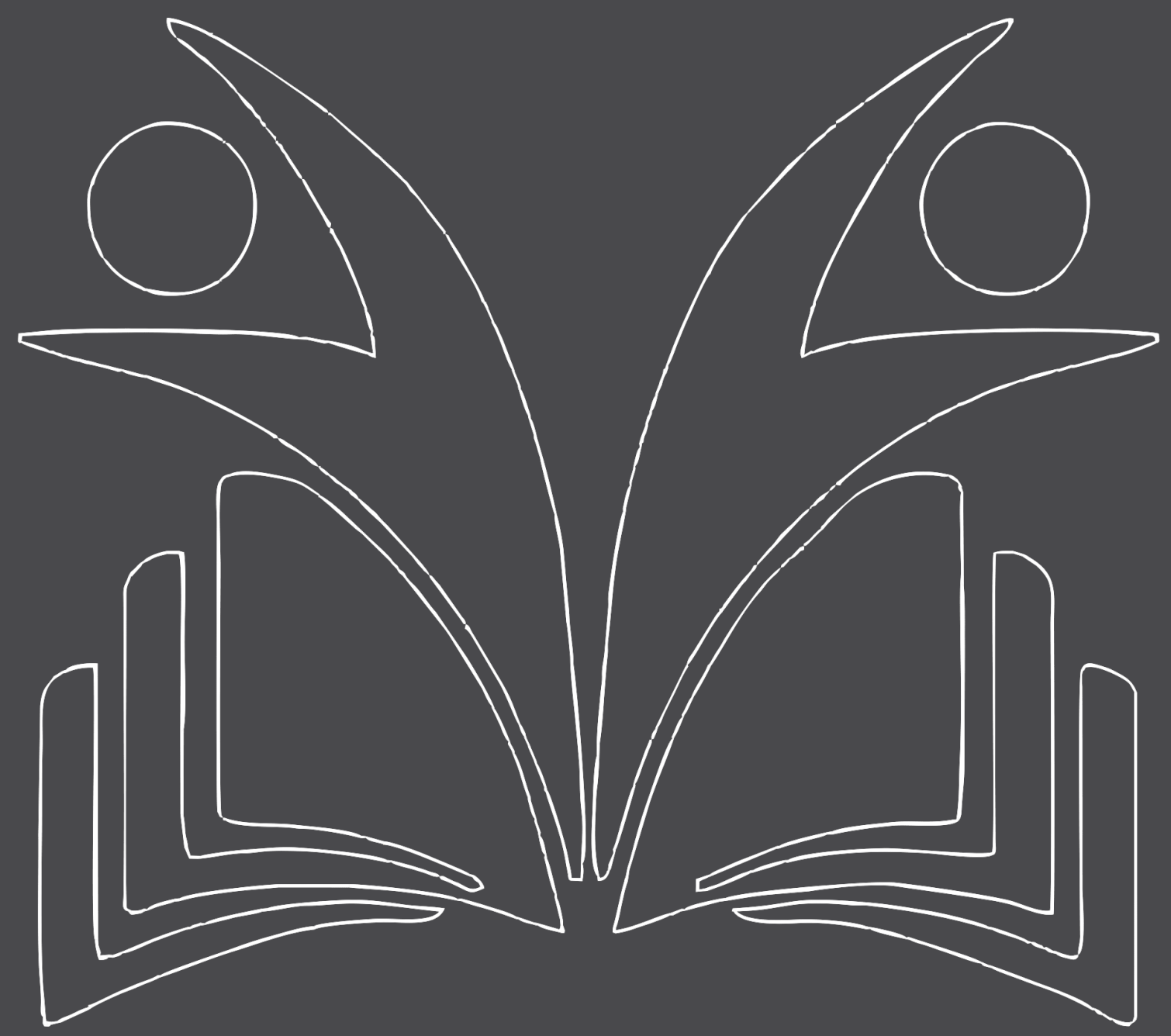


Dedico este trabalho a minha Familia, que sempre me apoiou e esteve ao meu lado, me incentivando na minha caminhada.

A minhas irmãs e minha mãe que são meu motivo mais importante, que me dão as forças necessarias para seguir meus objetivos e me inspiram cada dia. Ao meu esposo Jarmes, que me apoiou muito e não me deixou desistir nunca deste sonho.

Aos meus professores que foram sempre dedicados e pacientes e a toda turma do direito que colaboraram diariamente para melhorar o curso de Direito. 
"Não deixe que os seus medos tomem o lugar dos seus sonhos."

Walt Disney 
Resumo: O presente trabalho aborda o tema da exclusão do herdeiro indigno e a necessidade de uma sentença penal condenatória. No que tange a abertura de sucessões o herdeiro indigno depende de possíveis fatos que levam a exclusão de um herdeiro, sendo assim, trás a problematica no presente estudo, se a sentença penal é necessária ou não para que se concretize a exclusão. No Direito Sucessório para a exclusão do herdeiro por indignidade há a necessidade de condenação criminal ? Este debate a respeito da forma de definir os fatos que levam a indignidade e sua consequente exclusão da sucessão tem a finalidade de demonstrar como é conduzido o processo de descoberta do indigno e os procedimentos relevantes aos demais herdeiros para as devidas medidas a serem tomadas. Para isso, como objetivo geral, o mesmo abordará a respeito do regramento jurídico atual quanto à exclusão do herdeiro por indignidade e por sua vez analisar o Direito penal quanto a condenação criminal do excluído da sucessão, no que fere a figura da indignidade do herdeiro e a sua privação da herança. Para isso, abordará os seguintes objetivos específicos: a) abordar conceitos iniciais de família, do casamento, bem como analisar o instituto da sucessão e suas espécies; b) definir e conceituar a indignidade e as causas de exclusão do herdeiro indigno c) por fim, justificar a exclusão sucessória e as hipóteses de exclusão em razão da indignidade com o intuito de decidir se existe ou não a necessidade de uma sentença penal. A pesquisa fora realizada através do método dedutivo, buscando-se uma análise relativa das leis e jurisprudências, bem como casos relacionados ao tema, buscando demonstrar as ocorrências atuais na pratica. Como conclusão, tendo em vista os aspectos observados, podemos constatar que no direito sucessório brasileiro admite que uma pessoa seja excluída da sucessão na qual viria a ter direitos, a depender de atos praticados por ele, sendo assim essa se faz que a indignidade é ato reconhecido mediante uma ação de indignidade, estando essas causas de exclusão por indignidade em sua maioria tratadas pelo Código Civil, e ainda se conclui que não há necessidade de que haja uma sentença penal condenatória transitada em julgado para que seja declarada a indignidade, pois, trata-se de uma ação autônoma conforme expõe no transcorrer deste trabalho.

Palavras - chave: Sucessão; Indignidade; Exclusão; Herança; Sentença Penal. 


\section{Sumário}

1. INTRODUÇÃO

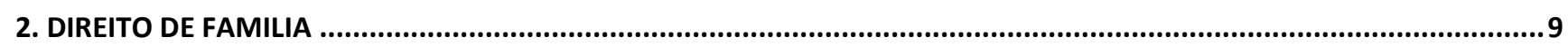

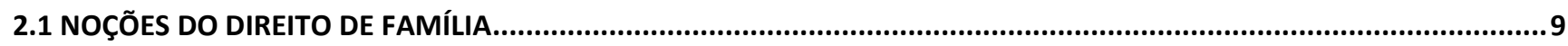

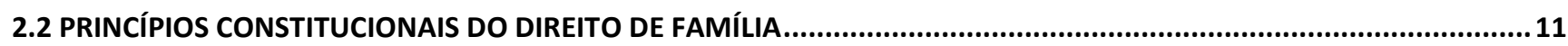

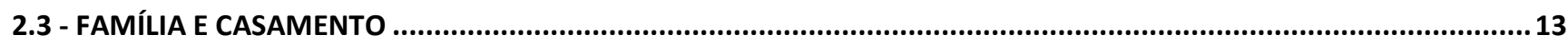

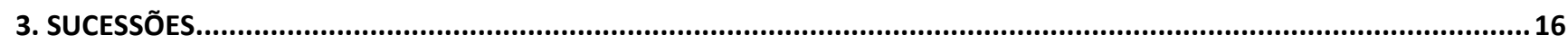

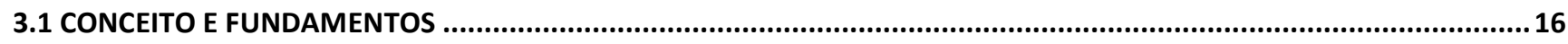

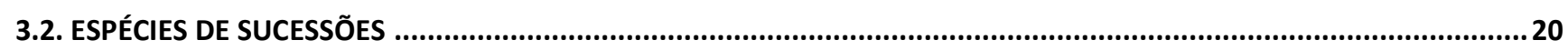

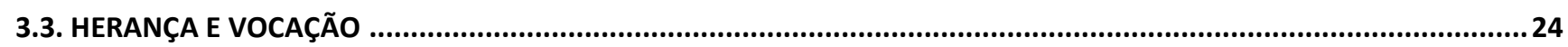

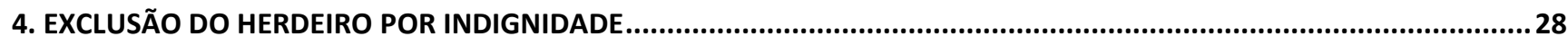

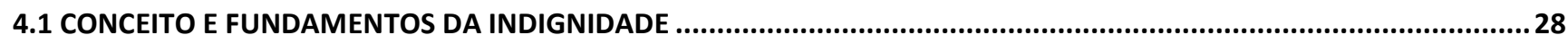

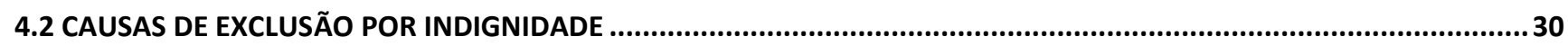

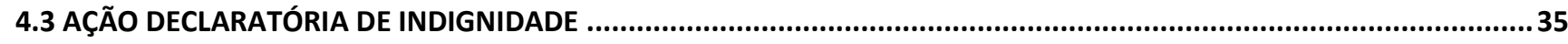

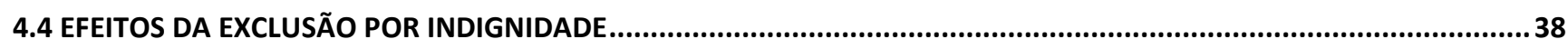

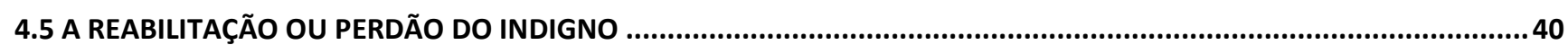

4.6 O PRINCÍPIO DA PRESUNÇÃO DE INOCÊNCIA E O PRINCÍPIO DO CONTRADITÓRIO ..................................................42

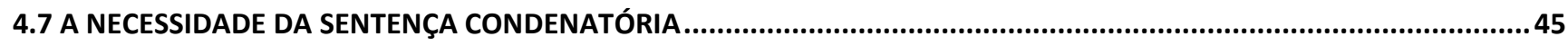

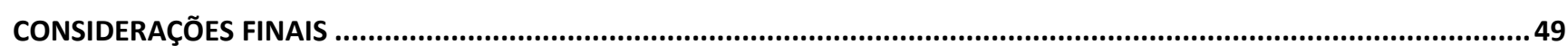

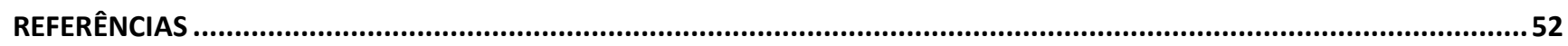




\section{INTRODUÇÃO}

Este trabalho tem como tema da exclusão do herdeiro indigno e a necessidade de uma sentença penal condenatória. No que tange a abertura de sucessões o herdeiro indigno depende de possíveis fatos que levam a exclusão de um herdeiro, sendo assim, trás a probelamtica no presente estudo, se a sentença penal é necessária ou não para que se concretize a exclusão.

Discorre acerca da exclusão do herdeiro indigno e a necessidade de sentença penal, o mesmo apresentado visa a definição do ato de indignidade bem como as consequências jurídicas e sociais para o indigno no Brasil. Neste momento, o herdeiro que até então era sucessor da herança, tanto pela ordem de vocação hereditária, que é a sucessão legítima; quanto por disposição de última vontade, que é a sucessão testamentária, passa então a ser privado do direito sucessório quando apurada tal condição e imposta a pena de exclusão por não ser este mais digno em recebê-la.

Indaga-se se existe a necessidade de uma sentença penal para que seja feita essa exclusão, conforme se ampara o princípio da presunção da inocência e do contraditório, dispostos na constituição federal no art. 5 o inciso LVXX. Com base nessa fundamentação se faz uma sucinta introdução ao traço histórico do direito de família ate a conciliação com o direito sucessório, sendo esses tópicos essenciais para a definição da tradição dos bens a serem sucedidos. Aduz teórica e pratica do advento da indignidade e sua introdução no ordenamento jurídico pátrio, buscando demonstrar sua aplicação no ordenamento jurídico brasileiro, através de exemplos vivenciados no Brasil. Faz algumas considerações sobre o entendimento de herança e como ela se dá legalmente, bem como o tratamento da doutrina e jurisprudência nacional quando a sucessão para o excluído determinado como indigno.

No Direito Sucessório para a exclusão do herdeiro por indignidade há a necessidade de condenação criminal?

Como objetivo geral o mesmo abordará a respeito do regramento jurídico atual quanto à exclusão do herdeiro por indignidade e por sua vez analisar o Direito penal quanto a condenação criminal do excluído da sucessão, no que fere a figura da indignidade do herdeiro e a sua privação da herança.

O presente trabalho tem como objetivos específicos, a) abordar conceitos iniciais de família, do casamento, bem como analisar o instituto da sucessão e suas espécies; b) definir e conceituar a indignidade e as causas de exclusão do herdeiro indigno c) por fim, justificar a exclusão sucessória e as hipóteses de exclusão em razão da indignidade com o intuito de decidir se existe ou não a necessidade de uma sentença penal. 
Em síntese o busca-se abranger os conceitos sobre o direito sucessórios e os direitos dos herdeiros legatários em defesa das ações do herdeiro indigno e indicar as possíveis soluções para proteger seus direitos no caráter sucessório frente ao princípio da presunção da inocência, pois presumindo-se inocente, ninguém será considerado culpado até o trânsito em julgado de sentença penal condenatória.

Com finalidade de explanar alguns pontos como os efeitos da exclusão do herdeiro indigno bem como a indignidade, tanto na sociedade quanto na família, sendo fundamentadas pelo código civil, assim como especificar se existe a necessidade de uma sentença criminal, ante a exclusão do indigno frente ao princípio da presunção da inocência elencado na constituição Federal Brasileira.

Após sua classificação o presente trabalho tambem dá enfoque na reinserção do indivíduo ao meio social, tendo como objetivos específicos conceituar a exclusão sucessória e fundamenta-la para assim entendermos o que é a indignidade e os atos que implicam a exclusão do herdeiro, e com base na a lei apontar o reconhecimento judicial na decretação da indignidade sucessória ante ao Direito civil.

Visando apresentar estudos sobre as definições caracterizadas no Código Civil e identificar a aplicação prática destas definições, diante da problematica constitucional da presunção de inocência e o contraditório para tal condenação. $O$ presente trabalho foi feito através de pesquisas que assim apresentam caráter teórico tendo em vista que discorrem a partir de aspectos voltados a teorias, leis, jurisprudências, códigos.

O método a ser utilizado será o dedutivo buscando-se uma análise relativa das leis e jurisprudências, bem como reportagens e casos que se relacionam ao assunto, em consequência demonstram as ocorrências atuais como leis bem como casos que já ocorreram dentro do tema localizados no Brasil.

A interdisciplinaridade do objeto de estudo é observada devido à inter-relação entre as disciplinas de Direito Penal, Direito Civil, Direito Constitucional as quais estão diretamente ligadas perante o histórico do tema, que evade desde os princípios constitucionais, em relação à família, como os direitos civis quanto a sucessões e ao direto penal principalmente em relação à classificação do indigno abordado neste estudo científico.

É relevante o presente estudo, pois cabe definir a importância da independência do direito civil, no que tange a sentença criminal, visando a celeridade dos procedimentos sucessórios substancialmente ao que se aplica a exclusão por indignidade, o que acarretará uma grande consequência jurídica e social. 


\section{DIREITO DE FAMILIA}

\subsection{NOÇÕES DO DIREITO DE FAMÍLIA}

Para se falar em família, devemos entender o seu conceito, que se trata de uma formação afetiva de pessoas que possuem o mesmo DNA e coabitam em regra no mesmo domicilio, em outras palavras, o conceito de família pode ser designado pelo laço afetivo de pessoas gerado através da formação de pessoas, registrado pelo ato civil conhecido como casamento.

Nas seguintes palavras podemos prever um conceito mais especifico, que considera a família como:

“Uma reunião de pessoas descendentes de um tronco ancestral comum, incluídas aí também as pessoas ligadas pelo casamento ou pela união estável, juntamente com seus parentes sucessíveis, ainda que não descendentes." (FIUZA, 2008, p. 939).

Ainda nesta conceituação podemos obter uma versão mais social sobre este instituto designado família onde o mesmo consiste em:

"Uma instituição social, composta por mais de uma pessoa física, que se irmanam no propósito de desenvolver, entre si, a solidariedade nos planos assistencial e da convivência ou simplesmente descendem uma da outra ou de um tronco comum". (NADER, 2006, p.3).

Designa-se por família como um conjunto de pessoas que possuem grau de parentesco entre si e de certa forma compartilham o mesmo lar. Uma família tradicional em regra é definida normalmente pela seguinte formação: pai e mãe, unidos por matrimônio ou união de fato, e por um ou mais filhos.

No direito positivo brasileiro atual, a expressão "família", na acepção jurídica do termo, não se limita, mas a noção religiosa católica. Família, consoante dispõe a lei, é a entidade constituída:
a) Pelo casamento civil entre o homem e a mulher;
b) Pela união estável entre o homem e a mulher;
c) Pela relação monoparental entre o ascendente e qualquer de seus descendentes. (LISBOA, 2013, p. 25).

Portanto, a família, que é a base da sociedade e deve ser protegida pelo Estado, pode ser formada a partir de diversas espécies de entidades ou unidades rubricadas como familiares.

Na área jurídica o tema possui uma definição mais restrita. Como regra geral, o Direito Civil considera membros da família apenas as pessoas unidas por relação conjugal ou de parentesco. As várias legislações definem, por sua vez, o âmbito do parentesco. A Constituição Federal de 1988 abrange a 
família como sendo o relacionamento entre um homem e uma mulher, podendo surgir o casamento ou uma união estável. Afirma também que pode ser composta pelo aspecto social.

\begin{abstract}
As leis em geral referem-se à família como um núcleo mais restrito, constituído pelos pais e sua prole, embora esta não seja essencial à sua configuração. É a denominada pequena família, porque o grupo é reduzido ao seu núcleo essencial: pai, mãe e filhos, correspondendo ao que os romanos denominavam domus. Trata-se de instituição jurídica e social, resultante de casamento ou união estável, formada por duas pessoas de sexo diferente com a intenção de estabelecerem uma comunhão de vidas e, via de regra, de terem filhos a quem possam transmitir o seu nome e seu patrimônio. (GONÇALVES, 2020, p. 3).
\end{abstract}

O direito de família estuda, em síntese, as relações das pessoas unidas pelo matrimônio, bem como aqueles que convivem em uniões sem casamento; dos filhos e das relações destes com os pais, da sua proteção por meio de tutela dos incapazes por meio da curatela.

Desse modo, importa considerar a família em um conceito amplo, como parentesco, ou seja, o conjunto de pessoas unidas por um vínculo jurídico de natureza familiar, porém esse conjunto não recebe tratamento pacífico e uniforme. A ordem jurídica enfoca-a em razão de seus membros, ou de suas relações recíprocas.

Porém, conforme o entendimento da sociedade vai evoluindo, o conceito de família vai se modificando, passando a existir vários tipos de família. Atualmente, o entendimento mais comum estabelece que família seja a união de pessoas ligadas pelo afeto.

Os novos conceitos conforme citados acima afetam diretamente no direito de família influenciando a criação de novos modelos de famílias como as afetivas citadas acima. Para a sociedade a simples relação de consanguinidade não é mais importante do que os laços afetivos e do que a própria convivência no âmbito familiar. A estrutura da família, teoricamente, é baseada nos laços de confiança, amor, respeito, reciprocidade, harmonia e bem-estar comum.

Em resumo a família representa a união entre pessoas que possuem laços sanguíneos e de convivência baseados no afeto, essa significação sobre família abrange diversas formas que encontram fundamentos na relação afetiva entre seus membros.

No entanto, não se trata de um conceito imutável. Ao longo da história, o conceito de famílias já assumiu diversos significados, porém, atualmente, o direito brasileiro assumiu de que a constituição familiar se fundamenta no afeto. Esse conceito então substitui o anterior, que baseava a família no matrimônio e na procriação, sendo um novo conceito mais aberto e fruto de maior progresso a na instituição de família. 
Uma demonstração desta mudança eventual é o Princípio da pluralidade familiar, uma vez que a norma constitucional abrange a família matrimonial e as entidades familiares.

É por meio do principio do pluralismo familiar que se permite que a família seja aceita tanto seja partir do casamento ou por união estável, respeitando dessa forma o principio da dignidade humana e da liberdade de constituir familiar seja qual forma for escolhida baseando-se no afeto até a consagração do poder familiar.

\subsection{PRINCÍPIOS CONSTITUCIONAIS DO DIREITO DE FAMÍLIA}

A da Constituição Federal de 1988 sinaliza importantes mudanças no sistema jurídico brasileiro, tendo em vista que a família vem sendo reconhecida não apenas pela formação dessas relações no âmbito material e extrapatrimonial, mas consolidando o conceito de núcleo formador da sociedade, de célula mater de onde se constroem todos os outros laços posteriores. Podemos induzir dessa forma, que a influência familiar é fundamentalmente relevante, ao considerarmos que em parte nossos problemas atuais, têm raiz no passado, na formação familiar, o que pode resultar inclusive no condicionamento de nossas escolhas e organizações afetivas.

A Constituição Federal de 1988, em seu artigo 1ำ, menciona que a República Federativa do Brasil, formada pela união indissolúvel dos Estados e Municípios e do Distrito Federal, constituída pelo Estado Democrático de Direito, destaca como seus principais fundamentos a soberania, a cidadania, a dignidade da pessoa humana, os valores sociais do trabalho e da livre iniciativa e o pluralismo político.

A Constituição no que respeita às relações estritamente familiares imputa deveres fundamentais ao Estado, à sociedade e à família.

Sendo, dessa maneira, os três grupos citados, constituídos por pessoas em uma relação de imputação de responsabilidades, não são meros detentores dos direitos fundamentais apenas, mas é delegada a esses grupos a responsabilidade que assenta sobre os deveres fundamentais.

Conforme a Constituição Federal estabelece ser à base da sociedade:

Art. 226. A família, base da sociedade, tem especial proteção do Estado.

$\S 1$ O O casamento é civil e gratuito a celebração.

$\S 2$ O O casamento religioso tem efeito civil, nos termos da lei.

§ 3ㅇ Para efeito da proteção do Estado, é reconhecida a união estável entre o homem e a mulher como entidade familiar, devendo a lei facilitar sua conversão em casamento. 
$\S 4$ ㅇ Entende-se, também, como entidade familiar a comunidade formada por qualquer dos pais e seus descendentes.

$\S 5$ o Os direitos e deveres referentes à sociedade conjugal são exercidos igualmente pelo homem e pela mulher.

$\S 600$ casamento civil pode ser dissolvido pelo divórcio.

$\S 70$ Fundado nos princípios da dignidade da pessoa humana e da paternidade responsável, o planejamento familiar é livre decisão do casal, competindo ao Estado propiciar recursos educacionais e científicos para o exercício desse direito, vedada qualquer forma coercitiva por parte de instituições oficiais ou privadas.

§ 8ㅇ O Estado assegurará a assistência à família na pessoa de cada um dos que a integram, criando mecanismos para coibir a violência no âmbito de suas relações. (BRASIL,1988, p.131).

Fica evidente, portanto, a importância atribuída à família, considerada como pilar principal de toda a sociedade e que como tal, obriga constitucionalmente o Estado em suas três esferas, federal, estadual e municipal.

Dessa forma, as alterações que o sucederam, tem como intuito, a preservação do núcleo familiar, sua concordância. Os valores atribuídos ao referido núcleo, conferem atualmente, um tratamento condizente à realidade social, com vistas a atender as necessidades reais da prole e laços afetivos entre os companheiros ou cônjuges, assim como, atender de forma satisfatória aos exigentes interesses da sociedade.

Portanto, são esses princípios especiais, próprios das relações familiares, que devem nortear as diversas situações que envolvam demandas familiares e que a ela estejam relacionados de algum modo.

Principio da dignidade Humana: Embora alguns doutrinadores possam garantir que não há hierarquia entre os princípios, o principio da dignidade da pessoa humana, é o princípio de maior, fundamento do Estado Democrático de Direito, sendo afirmado já no primeiro artigo da Constituição Federal.

Conforme a Constituição Federal de 1988, em seu art. 1으, III, tratando-o como valor fundamental, dispõe:

Art. 1 A República Federativa do Brasil, formada pela união indissolúvel dos Estados e Municípios e do Distrito Federal, constitui-se em Estado Democrático de Direito e tem como fundamentos:

III - a dignidade da pessoa humana (BRASIL, 1988, p.11). 
Essa preocupação com os direitos humanos, bem como a paz social, conduziu o constituinte, a consolidar a dignidade da pessoa humana como valor supremo, identificado sob o status do primeiro principio de manifestação dos valores.

A Constituição Federal dispõe do seguinte modo:

Art. 227. É dever da família, da sociedade e do Estado assegurar à criança, ao adolescente e ao jovem, com absoluta prioridade, o direito à vida, à saúde, à alimentação, à educação, ao lazer, à profissionalização, à cultura, à dignidade, ao respeito, à liberdade e à convivência familiar e comunitária, além de colocálos a salvo de toda forma de negligência, discriminação, exploração, violência, crueldade e opressão. (BRASIL, 1988, p.132).

Constitui assim, o principio da dignidade da pessoa humana, a base do núcleo familiar, garantindo a todos os elementos que a integra o desenvolvimento pleno, principalmente da criança e do adolescente. Sendo estes principais quanto ao o poder familiar que se conceitua como o conjunto de deveres e direitos dos pais em relação aos filhos, e aos seus bens e usufrutos.

Versa-se sobre os princípios familiares com base no Direito de Família, pois o mesmo deve ser analisado sob o aspecto constitucional, tendo como finalidade verificar um novo tratamento a este ramo do direito, um tratamento das pessoas em detrimento dos bens.

\section{3 - FAMÍLIA E CASAMENTO}

O casamento como todas as instituições sociais varia com o tempo, sendo seu conceito a união entre duas pessoas, com a finalidade de cultivar e multiplicar a vida. Muitos significam o conceito do mesmo como um fundamento para a sociedade.

O Casamento é considerado como uma entidade familiar levando em consideração a Constituição Federal de 1988, sendo conhecida como a entidade mais antiga e mais conhecida sociedade. Conforme o seguinte autor "Casamento é o contrato de direito de família que tem por fim promover a união do homem e da mulher, de conformidade com a lei, a fim de regularem suas relações sexuais, cuidarem da prole comum e se prestarem mútua assistência." (RODRIGUES, 2004, p.19).

O casamento, portanto, pode ser considerado como um tipo de contrato que regula a união de duas pessoas, sendo essa a base para a formação de uma família.

A construção do conceito de família se inicia no casamento, dando espaço para a procriação da prole, baseado nos aspectos sociais e conceitos primitivos. Que alegam, desde os princípios sobre a sagrada 
família, sendo o pai e a mãe, para a concepção de um filho, servindo como espelho para as religiões fundadas no cristianismo.

Sendo assertiva essa afirmação, podemos compara-la com significação do cristianismo:

O Cristianismo, como obtempera Caio Mário elevou o casamento à dignidade de um sacramento, pelo qual "um homem e uma mulher selam a sua união sob as bênçãos do céu, transformando-se numa só entidade física e espiritual (caro una, uma só carne), e de maneira indissolúvel (quos Deus coniunxit, homo non separet)". (GONÇALVES, 2019, p.2).

Conforme a afirmação do autor acima se pode aludir ao dito de grande conhecimento da igreja católica, também conhecido como um dos sete sacramentos da igreja, sendo o casamento o mais sagrado, na concepção da igreja, a separação não é uma hipótese, sendo o elo formado findado apenas pela morte.

Para os fins sociais o casamento representa muito mais que a união de duas pessoas, é o compartilhar da vida em conjunto, sendo física, espiritual ou patrimonial.

No âmbito do direito o casamento é classificado como o instituto civil pelo meio do qual, atendida às conformidades legais, quais sejam a habilitação, celebração e registro, em cartório no caso, se estabelece entre duas pessoas a comunhão plena de vida em família, com base na igualdade de direitos e deveres, vinculando os cônjuges reciprocamente como consortes entre si e responsáveis pelas obrigações da família.

No direito brasileiro, duas definições são consideradas clássicas. A primeira, de Lafayette Rodrigues Pereira, proclama: "O casamento é um ato solene pelo qual duas pessoas de sexo diferente se unem para sempre, sob promessa recíproca de fidelidade no amor e da mais estreita comunhão de vida". Ressente-se também, ao conceituar o casamento como "um ato", da referência à sua natureza contratual, porque a religião o elevava à categoria de sacramento.

A segunda definição referida é a de Clóvis Beviláqua, nestes termos: “O casamento é um contrato bilateral e solene, pelo qual um homem e uma mulher se unem indissoluvelmente, legalizando por ele suas relações sexuais, estabelecendo a mais estreita comunhão de vida e de interesses, e comprometendo-se a criar e a educar a prole, que de ambos nascer". Pontes de Miranda, embora a considere mais jurídica e mais acorde com os nossos tempos, a critica por se referir à indissolubilidade do vínculo, quando não são, todavia, indissolúveis os seus efeitos, e por se referir a apenas um deles. A definição de Beviláqua tem a virtude de aderir à concepção contratualista e de enfatizar a tradicional e estreita comunhão de vida e de interesses, realçando o mais importante dos deveres, que é o relacionado à prole. (GONÇALVES, 2019, p.2). 
Embora, seu conceito no âmbito popular seja de extrema importância para os meios sociais, o que mais contribui pra a regularidade da mesma, é o que se dá no âmbito civil.

A partir do momento que os atos legais para a concessão desse instituto jurídico estão concluídos, o casamento se torna registrado oficialmente se tornando uma determinação de estado, por isso a denominação de estado civil.

Porém para oficialização existem os tipos de regime do casamento, o que contribui inteiramente na resolução civil, durante a vida dos casados, e após a causa morte, através de sucessões. É através da definição do regime que se incubem a divisão ou não dos bens e patrimônios que serão compartilhados ou não com o cônjuge ou herdeiros.

Os regimes de bens no casamento são um conjunto de regras que os noivos escolhem antes do casamento. Elas determinam juridicamente como serão administrados os bens do casal.

São 3 tipos de regimes de casamento: a comunhão parcial de bens, comunhão universal de bens e a separação de bens: a comunhão parcial significa partilhar em igual proporção, o que seria metade para cada, ou seja, os bens adquiridos antes do casamento não se compartilham entre os cônjuges, mas, os bens constituídos durante a união passam a pertencer a ambos os cônjuges. Desta forma, não há o que se falar em quem contribuiu mais durante a união, o regime estabelece o compartilhamento destes a partir da instituição do mesmo no casamento.

Na comunhão universal tanto os bens adquiridos antes como durante o casamento se compartilham entre os cônjuges, ou seja, ficam pertencendo ao casal, formando assim um único patrimônio para casal. Quando há o termo "comunhão" no nome do regime de bens, há "meação".

A meação é a divisão de metade do patrimônio acumulado por um casal, essa divisão se dá conforme o regime de comunhão, sendo metade para cada cônjuge. Porém, enquanto no regime de comunhão parcial a meação ocorre somente para os bens comuns ao casal durante a união, na comunhão universal a meação ocorre para todos os bens sendo anteriores ou perante a união.

No regime de separação de bens, como o nome já conceitua os bens de ambos os cônjuges não se compartilham, sendo assim os bens adquiridos antes e durante o casamento continuarão pertencendo ao seu respectivo proprietário.

O Código Civil impõem que, nesse regime de casamento, os dois cônjuges contribuam para as despesas do casal na proporção dos seus rendimentos, a não ser que ajuste de modo diverso, o que poderá ser feito no pacto antenupcial. 
Sendo essa vertente do casamento pode-se concluir que a sua finalidade é a criação de uma nova família, visto que essa se inicia legalmente, no âmbito do direito civil, a partir do mesmo.

São múltiplas as finalidades do casamento e variam conforme a visão filosófica, sociológica, jurídica ou religiosa como são encaradas. Segundo a concepção canônica, matrimonii finis primarius est procreatio atque educatio prolis; secundarius muttum adiutorium et remedium concupiscentiae, ou seja, o fim principal do matrimônio consiste na procriação e educação da prole; e o secundário, na mútua assistência e satisfação sexual. (GONÇALVES, 2017, p.13).

Portanto, a principal finalidade do casamento é estabelecer uma comunhão plena de vida, motivada pelo amor e afeição existente entre o casal e baseada na igualdade de direitos e deveres dos cônjuges e na mútua assistência.

Tendo em via essa finalidade os regimes de casamento servem apenas para meros encargos de registro civil.

\section{SUCESSÕES}

\subsection{CONCEITO E FUNDAMENTOS}

O direito das sucessões em regra tem sua definição geral exposta pela seguinte autora que o diz: "É composto do conjunto de normas que disciplinam a transferência do patrimônio de alguém, depois de sua morte, ao herdeiro, em virtude de lei ou testamento." (DINIZ, 2014, p.33).

O direito sucessório é o evento que se dá pelo denominado causa mortes, assim se sucede aos seus herdeiros e sucessores os bens de forma da ultima vontade do falecido também denominado como de cujos.

O conceito do direito sucessório se baseia em resumo no direito hereditário, conjunto de princípios jurídicos que disciplinam a transmissão do patrimônio de uma pessoa que morreu a seus sucessores; complexo dos princípios segundo os quais se realiza a transmissão do patrimônio de alguém que deixa de existir. Em sentido objetivo, é o conjunto das normas reguladoras da transmissão dos bens e obrigações de um indivíduo em consequência de sua morte.

No sentido subjetivo, o direito de suceder, isto é, de receber a herança ou o acervo hereditário do falecido, sendo este também denominado como conjunto de princípios jurídicos que disciplinam a transmissão do patrimônio de uma pessoa que morreu a seus sucessores.

Voltando a história antes das leis do código civil podemos relembrar fatos como no direito romano primitivo o qual o herdeiro era mais um continuador do falecido que o sucessor dos bens deixados 
pelo mesmo, ou seja, aquele que recebia a herança determinada continuava o legado de quem o sucedeu. Portanto o intuito principal da sucessão hereditária nesta época seria dar continuidade do grupo familiar. A transmissão dos direitos patrimoniais seria uma consequência da sucessão.

O homem, pouco importando a época ou sua crença, sempre acreditou, ou ao menos esperou poder transcender o acanhado lapso da vida. Há uma ideia central inerente no corpo social, que é a da figura do sucessor. Essa noção parte de uma das ficções mais aprofundadas no pensamento social, ou seja, a ideia de continuação ou continuidade da pessoa falecida (autor da herança) na pessoa do sucessor universal.

A ideia da sucessão por causa da morte não aflora unicamente no interesse privado: o Estado também tem o maior interesse de que um patrimônio não reste sem titular, o que lhe traria um ônus a mais. Para ele, ao resguardar o direito à sucessão, está também protegendo a família e o ordenando sua própria economia. Se não houvesse direito à herança, estaria prejudicada a própria capacidade produtiva de cada indivíduo, que não teria interesse em poupar e produzir, sabendo que sua família não seria alvo do esforço.

O direito das sucessões disciplina, portanto, a projeção das situações jurídicas existentes, no momento da morte, da desaparição física da pessoa a seus sucessores. A primeira ideia, com raízes históricas, é de que a herança (o patrimônio hereditário) se transfere dentro da família. Daí então a excelência da ordem de vocação hereditária inserida na lei: a chamada "sucessão legítima". O legislador determina uma ordem de sucessores, a ser estabelecida, no caso de o falecido não ter deixado testamento, ou quando, mesmo perante a existência de ato de última vontade, este não puder ser cumprido.

Portanto com base no histórico das sucessões a constituição federal continuou em 1988 a manter o direito sucessório em seu artigo 5ำ dando o conceito ao direito das sucessões, que nada mais é que, o conjunto de normas que disciplinam a transferência do patrimônio (ativo e passivo, créditos e débitos) de alguém, depois de sua morte, em virtude de lei ou testamento. Está regulada nos artigos 1.784 a 2.027 CC. A Constituição Federal assegura o direito de herança (artigo 5o, XXX).

Nós, representantes do povo brasileiro, reunidos em Assembleia Nacional Constituinte para instituir um Estado Democrático, destinado a assegurar o exercício dos direitos sociais e individuais, a liberdade, a segurança, o bem-estar, o desenvolvimento, a igualdade e a justiça como valores supremos de uma sociedade fraterna, pluralista e sem preconceitos, fundada na harmonia social e comprometida, na ordem interna e internacional, com a solução pacífica das controvérsias, promulgamos, sob a proteção de Deus, a seguinte Constituição da República Federativa do Brasil. 
Art. 5o Todos são iguais perante a lei, sem distinção de qualquer natureza, garantindo-se aos brasileiros e aos estrangeiros residentes no País a inviolabilidade do direito à vida, à liberdade, à igualdade, à segurança e à propriedade, nos termos seguintes:

XXX - é garantido o direito de herança. (BRASIL, 1988, p.14).

Segundo explanado acima, necessita-se dar a devida abertura da sucessão para a divisão dos bens, ou o compartilhamento organizado entre os sucessores, se dá a seguinte expressão "aberta à sucessão" que se refere ao momento em que surgem os direitos sucessórios, sem fazer referência, entretanto, aos titulares desses direitos. "Art. 1.784. Aberta a sucessão, a herança transmite-se, desde logo, aos herdeiros legítimos e testamentários." (BRASIL, 2002, p.371).

Sendo assim, a sucessão é considerada aberta no instante da morte ou do que se se presume a morte de alguém. É nesse instante que nasce o direito hereditário e ocorre a substituição do falecido pelos seus sucessores (herdeiros), aplicando-se em todas as relações jurídicas em que o falecido estava vinculado.

Em continuação, o evento que se denomina causa mortis se refere ao falecimento do autor da herança e a expressão de cujus, se deve a nominação também do falecido, essas qualificações se dão baseadas ao principio de Saisine.

Essa forma de sucessão dada pela morte natural consiste no principio de saisine que consiste no Direito das Sucessões que disciplina a transmissão do patrimônio do de cujus (aquele que sofreu a morte natural) para seus sucessores.

É bem comum vermos a confusão dos dois termos. Para esclarecer, os Direitos das Sucessões não têm nada a ver com herança, pois, quando falamos em sucessão nos referimos ao ato de alguém substituir outrem nos direitos e obrigações, em função da morte. Já a herança é o conjunto de direitos e obrigações transmitidas aos nomeados ou herdeiros em patrimônio, em virtude da morte do dono do patrimônio.

Obviamente que os pressupostos do direito das sucessões para que tenhamos um processo relativo ao Direito Sucessório deve-se haver a morte do de cujus (o autor da herança). Além disso, deve-se ter a vocação hereditária dos que pleiteiam a sucessão.

Conforme definido pelo Art. 1.829, a sucessão legítima é reconhecida em uma ordem estabelecida e considera os seguintes sucessores: 
Artigo. 1829 do Código Civil.

A sucessão legítima defere-se na ordem seguinte:

I - aos descendentes, em concorrência com o cônjuge sobrevivente, salvo se casado este com o falecido no regime da comunhão universal, ou no da separação obrigatória de bens (art. 1.640, parágrafo único); ou se, no regime da comunhão parcial, o autor da herança não houver deixado bens particulares;

II - Aos ascendentes, em concorrência com o cônjuge;

III - ao cônjuge sobrevivente;

IV - Aos colaterais. (BRASIL, 2002, p.377).

Portanto para se corroborar sobre sucessões, deve-se haver sobre os requisitos acima como pressupostos de sua legitimidade para suceder.

Para impor os demais pressupostos o direito sucessório tem como principio fundamental o Princípio da Saisine que prevê o direito dos herdeiros de receber desde logo a herança. Ou seja, se aberta à sucessão, com o evento causa mortes e o falecido não deixou testamento, prevalecerá o princípio da Saisine.

Sendo assim não havendo testamento se aplicará o principio de Saisine como falamos, porém, havendo o testamento como registro de ultima vontade do de cujos, será o mesmo usado na transmissão hereditária. Atualmente ocorre que na prática, o que prevalece é a última vontade do de cujos feita através de testamento.

Mesmo estabelecido que se prevalece a ultima vontade testamentaria do de cujos o princípio da saisine, segue-se da seguinte forma para seus respectivos efeitos:

1- Abre-se a herança com a morte do sujeito, e no mesmo instante os herdeiros a adquirem. Verifica-se, portanto, imediata mutação subjetiva; 2 - Não é o fato de estar próximo que atribui ao herdeiro a posse e propriedade dos bens, mas sim a sucessão - a posse e a propriedade advêm do fato do óbito; 3- O herdeiro passa a ter legitimidade ad causam (envolvendo a faculdade de proteger a herança contra a investida de terceiros); 4- Com o falecimento do herdeiro após a abertura da sucessão, transmite-se a posse e propriedade da herança aos seus sucessores, mesmo sem manifesta aceitação; 5- mesmo que os bens não estejam individualizados e discriminados, constitui a herança em si mesma um valor patrimonial, e, como tal, pode ser transmitida inter- vivos. (PEREIRA, 2017, p.20).

O objetivo deste princípio é assegurar que de certa forma o patrimônio deixado, que em regra deve ser transferido de imediato aos sucessores, não fique sem titular, pois ate que se organize a transferência definitiva dos bens, deve se prevalecer que ocorreu a causa mortes, dando a abertura da sucessão, portanto essa se implica para garantir os bens aos sucessores do falecido. 
Nestas condições fica previsto no seguinte artigo, sobre o prevalecimento do testamento em meio à abertura da sucessão, no que se diz respeito aos herdeiros legítimos.

“Art. 1.788. Morrendo a pessoa sem testamento, transmite a herança aos herdeiros legítimos; o mesmo ocorrerá quanto aos bens que não forem compreendidos no testamento; e subsiste a sucessão legítima se o testamento caducar, ou for julgado nulo." (BRASIL, 2002, p.371).

Portanto, inexistindo testamento, a herança será transmitida aos herdeiros legítimos, estes receberão o que lhes competem através da partilha. E aos bens compreendidos no ato de disposição de última vontade, através do testamento, serão partilhados os bens conforme o registro, não havendo o que se falar em herdeiro necessário para dispor dos bens.

\subsection{ESPÉCIES DE SUCESSÕES}

Conforme explanado no tópico anterior a finalidade da sucessão é dar continuidade à relação jurídica no que se refere a propriedade patrimonial através da transmissão dos bens do de cujus para os seus sucessores. Como bem abordado a sucessão ocorre através do evento causa mortis, que finda a vida do de cujos, o que sucede dando seguimento após a esse fatídico evento se denomina sucessão, a quem será passado os direitos patrimoniais para se dar a devida continuidade do grupo familiar.

No código civil existem vários tipos de sucessões que estão qualificadas mediante as numerosas variantes que falaremos a seguir, porém as principais sucessões que se dão através da causa morte, são a sucessão legitima e a sucessão testamentária, as quais já tiveram sua prévia definição anteriormente.

Pois bem, no que se diz a sucessão legitima podemos defini-la como aquela que não é testamentaria, ou seja, ela ocorrerá em caso de o falecido não ter deixado o testamento para suceder aos seus herdeiros. Podemos ter uma visão mais expressa baseado nas seguintes palavras:

Se não há testamento, se o falecido não deixar qualquer ato de última vontade, a sucessão é legítima ou ab intestato, deferido todo o patrimônio do de cujus às pessoas expressamente indicadas pela lei, de acordo com a ordem de vocação hereditária (CCB, art. 1829). Assim estabelece o art. 1788: 'morrendo a pessoa sem testamento, transmite a herança aos herdeiros legítimos; o mesmo ocorrerá quanto aos bens que não forem compreendidos no testamento; e subsiste a sucessão legítima se o testamento caducar, ou for julgado nulo. A essas hipóteses acrescenta-se a revogação do testamento (MONTEIRO, 2003, p. 9). 
A mesma ocorre de acordo com a lei, presumindo desta forma que aquele que faleceu desde que não tenha deixado o testamento, não possui sua ultima vontade declarada, portanto a sucessão será conforme a lei dispõe.

Sendo assim a herança transmitida aos herdeiros legítimos em primeiro lugar, como filhos e cônjuge e os seguintes conforme previsto no seguinte artigo:

Artigo 1.829. A sucessão legítima defere-se na ordem seguinte:

I - aos descendentes, em concorrência com o cônjuge sobrevivente, salvo se casado este com o falecido no regime da comunhão universal, ou no da separação obrigatória de bens (art. 1.640, parágrafo único); ou se, no regime da comunhão parcial, o autor da herança não houver deixado bens particulares;

II - Aos ascendentes, em concorrência com o cônjuge;

III - ao cônjuge sobrevivente;

IV - Aos colaterais. (BRASIL, 2002, p.377).

Seguindo o previsto artigo que incorre sobre os herdeiros legítimos podemos concluir que morrendo a pessoa sem testamento transmite-se a herança aos herdeiros legítimos indicados pela lei.

Esse tipo de sucessão também poderá ocorrer dentre as seguintes hipóteses que podem ser consideradas como disposições da legítima. Em primeira hipótese quando há testamento e o autor não dispões da integralidade de seus bens, constando apenas parte deles e sobre outra parte nada manifesta, serão partilhados o restante dos bens na forma da sucessão legitima.

Em segunda, existe a possibilidade de caducidade do testamento ou até a nulidade do mesmo. Nesse caso, a sucessão será deferida na ordem legal de vocação hereditária às pessoas expressamente indicadas no art. 1.829 do Código Civil.

Portanto, pode-se concluir que sucessão legatária somente ocorre quando o falecido não deixa testamento, ou quando o mesmo venha a perder sua validade ou até mesmo ser julgado nulo. Estes bens serão destinados em primeiro lugar aos herdeiros descendentes, como por exemplo: filhos, netos e bisnetos concorrendo com o cônjuge.

Em segundo lugar são chamados a suceder os ascendentes, que são: os pais, avós e bisavós concorrendo também com o cônjuge. No caso de não existir descendentes ou ascendentes, a herança será assim transmitida completamente ao cônjuge.

Ainda se não houver nem um tipo dos herdeiros classificados acima, como designa a lei os bens serão destinados aos herdeiros colaterais que são: os irmãos, sobrinhos, tios. 
Caso o falecido não fosse casado, mas tivesse em união estável, o companheiro sobrevivente poderá concorrer à herança destinada aos herdeiros colaterais.

Na falta de todos os herdeiros listados acima ou em caso de renuncia da herança por todos eles, o direito sucessório será transmitido para o Município ou ao Distrito Federal. Sendo, assim os bens passam ao domínio do Poder Púbico por meio de sentença declaratória de vacância, portanto, após cinco anos da abertura da sucessão serão de propriedade publica.

Sem mais podemos dispor a respeito desta espécie de sucessão que a mesma só será deferida por determinação legal.

A outra espécie de sucessão comum, conforme já abordamos no decorrer deste trabalho, é a sucessão testamentária, podemos conceitua-la como a disposição de ultima vontade do falecido ou de cujos. Sendo assim o disposto no documento registrado deverá prevalecer. "Testamento pode ser definido como negócio jurídico solene pelo qual alguém, nos termos da lei, dispõe de seus bens, no todo ou em parte, para depois de sua morte". (CAHALI, 2003, p.28).

Portanto, o testamento é o documento pelo o qual um individuo ainda em vida manifesta sua ultima vontade em vida, designando seus bens e patrimônios a quem ele acha que deve receber, ou seja, o autor da herança define qual bem irá para qual herdeiro.

O regramento jurídico que fundamenta o processo de testamento se prevê no seguinte artigo:

Art. 1.857. Toda pessoa capaz pode dispor, por testamento, da totalidade dos seus bens, ou de parte deles, para depois de sua morte.

$\S 10$ A legítima dos herdeiros necessários não poderá ser incluída no testamento.

§ 20 São válidas as disposições testamentárias de caráter não patrimonial, ainda que o testador somente a elas se tenha limitado. (BRASIL, 2002, p.380).

Conforme o artigo supramencionado, havendo herdeiros legítimos, ou necessários, o de cujus só poderá deixar em testamento metade do seu patrimônio, pois conforme dispõe o mesmo a outra metade é legitimamente assegurada aos herdeiros.

Os herdeiros necessários são em regra o cônjuge sobrevivente, descendentes ou ascendentes, esta regra se confirma através do disposto no seguinte artigo: “Art. 1789. Havendo herdeiros necessários, o testador só poderá dispor da metade da herança." (BRASIL, 2002, p.371).

Portanto, não há o que se falar sobre a legítima assegurada aos herdeiros necessários. A parte legítima herdará a metade dos bens do testador, do qual os herdeiros necessários não podem ser privados. 
Não havendo os herdeiros necessários o testador terá plena liberdade de testar. Mas se for casado sob o regime da comunhão universal de bens o patrimônio do casal será dividido em duas meações conforme o seguinte artigo: "Art. 1.667. O regime de comunhão universal importa a comunicação de todos os bens presentes e futuros dos cônjuges e suas dívidas passivas, com as exceções do artigo seguinte." (BRASIL, 2002, p.356). Sendo esse o caso a pessoa só poderá dispor da sua meação.

Em nosso ordenamento é proibida qualquer outra forma de sucessão, especialmente a contratual. São proibidos os pactos sucessórios, não podendo ser objeto de contrato a herança de pessoa viva este requisito está expressamente estipulado no artigo 426 do código civil como podemos ver a seguir: “Art. 426. Não pode ser objeto de contrato a herança de pessoa viva." (BRASIL, 2002, p.192).

Portanto, pode se dizer que a lei veta qualquer tipo de contrato sob herança de pessoa viva. No entanto este dispositivo admite a cessão de direitos.

A cessão de direitos é um contrato pelo o qual se realiza a transmissão de direitos derivados de sucessão, enquanto não dados à partilha. Este se dá de acordo com o seguinte artigo:

Art. 1793- 0 direito à sucessão aberta, bem como o quinhão de que disponha o coerdeiro, pode ser objeto de cessão por escritura pública.

$\S 1$ o Os direitos, conferidos ao herdeiro em consequência de substituição ou de direito de acrescer, presumem-se não abrangidos pela cessão feita anteriormente. (BRASIL, 2002, p.372).

De acordo com o artigo supramencionado, podemos concluir que o herdeiro pode fazer a cessão de seus direitos, o que fica implícito que o coerdeiro, que receber esta cessão não poderá fazer o mesmo. A título universal o herdeiro é chamado para suceder na totalidade da herança, fração ou parte dela, assumindo a responsabilidade relativamente ao passivo. Ocorre tanto na legítima como na testamentária.

A título singular o testador deixa ao beneficiário um bem certo e determinado e o herdeiro em resumo, podemos concluir que a sucessão testamentária é conduzida pelo testamento, sendo este instrumento usado em deposição da ultima vontade do autor da herança para contemplar herdeiros, que sucedem a título universal, legatário ou a título singular.

Ao transcender desta segunda espécie de sucessão, podemos notar que a mesma é personalíssima, pois conta como ato de ultima vontade, e, portanto, deve prevalecer sobre a lei de sucessão hereditária. 
Sendo assim mesmo sendo um instrumento personalíssimo, o mesmo poderá ser revogável no seguinte caso.

Se o autor ainda em vida se arrepender ele poderá mudar alguma disposição ou ainda revogá-lo por completo. Assim dispõe o seguinte artigo do Código Civil: "Art. 1.858. O testamento é ato personalíssimo, podendo ser mudado a qualquer tempo." (BRASIL, 2002, p.380).

Vale significar que essa espécie assegura parte da herança os filhos futuros que o autor do testamento, não vier a especificar no mesmo. “Art. 1.799- Na sucessão testamentária podem ainda ser chamados a suceder, I - os filhos, ainda não concebidos, de pessoas indicadas pelo testador, desde que vivas estas ao abrir-se a sucessão." (BRASIL, 2002, p.373).

Portanto existe a possibilidade de dispor aos filhos não concebidos até a morte do testador, sendo assim estes também podem adquirir parte de seu patrimônio se houver previsão no testamento, desde que tenha a indicação da pessoa que conceberá seu filho e esta esteja viva quando houver a abertura da sucessão. Esta hipótese em regra se aplica aos filhos nascidos por reprodução assistida.

\subsection{HERANÇA E VOCAÇÃO}

Para se falara de herança, devemos abranger sobre seu conceito, ante o exposto, pode-se definir a herança como os bens a serem sucedidos aos sucessores advindos da causa mortis de outra pessoa. Ou seja, mediante a abertura da sucessão o herdeiro se beneficiará dos bens deixados pelo de cujos, seja na sucessão legal ou testamentária.

Sendo este a receber a herança legitimo da forma que se enquadrar da especie de sucessão estimada. Explicita da transmissão da herança o disposto no art. 1.791 do codigo civil:

Art. 1.791. - A herança defere-se como um todo unitário, ainda que vários sejam os herdeiros.

Parágrafo único. Até a partilha, o direito dos co-herdeiros, quanto à propriedade e posse da herança, será indivisível, e regular-se-á pelas normas relativas ao condomínio. (BRASIL, 2002, p.372).

$\mathrm{O}$ artigo supratranscrito e seu parágrafo único reafirmam duas ideias fundamentais do direito sucessório:

a) da devolução unitária da herança aos herdeiros;

b) a noção de indivisibilidade do monte hereditário, no momento da abertura da sucessão, até a partilha final. 
Antes da partilha, nenhum herdeiro tem a propriedade ou a posse exclusiva sobre um bem certo e determinado do acervo hereditário. Só a partilha individualiza e determina objetivamente os bens que cabem a cada herdeiro. Julgada a partilha, diz o artigo: "Art. 2.023. Julgada a partilha, fica o direito de cada um dos herdeiros circunscritos aos bens do seu quinhão." (BRASIL, 2002, p.399).

A herança, tanto quanto o patrimônio, são classificados entre as universalidades de direito. Não se confunde com o acervo hereditário constituído pela massa dos bens deixados, porque pode comporse apenas de dívidas, tornando-se passiva.

Não é suscetível de divisão em partes materiais enquanto permanece como tal. É a data da abertura da sucessão que determina a devolução da herança, que produz o seu efeito translativo.

Deferindo-se como "um todo unitário" a transmissão dos direitos do de cujus se opera de plano. É nesse momento que nasce a indivisão, no caso de pluralidade de herdeiros. E quando ocorrer a divisão, com seu efeito declarativo (na partilha), é a esta data que remontarão os direitos privativos dos herdeiros sobre os bens correspondentes a suas cotas respectivas.

Portanto, fica declarado que não há transmissão da herança sem a necessária vocação hereditária. Vocação hereditária é a convocação de pessoa com direito à herança, para que receba o patrimônio deixado pelo falecido. Para receber essa transmissão ficou explicito que se deve ser legitimo, portanto ficam serão esses conforme dispõe do artigo 1.798 do Código Civil: "Artigo 1.798 - Legitimam-se a suceder as pessoas nascidas ou já concebidas no momento da abertura da Sucessão." (BRASIL, 2002, p.373).

Pode se falar em vocação hereditária nos seguintes casos: Situação do cônjuge: Anteriormente era correto afirmar que os ascendentes herdavam antes dos descendentes, todavia, isso mudou e o cônjuge foi alçado à categoria de herdeiro necessário, concorrendo (dependendo do regime) com descendentes e (independentemente do regime) com ascendentes, logo nas primeiras convocações sucessórias. Sendo assim, qualquer que seja o regime de bens o direito real de habitação será assegurado ao cônjuge e relativamente ao imóvel destinado à moradia da família, desde que seja o único daquela natureza a inventariar, conforme podemos ver no seguinte artigo, é um típico direito real sobre coisa alheia.

Art. 1.831. Ao cônjuge sobrevivente, qualquer que seja o regime de bens, será assegurado, sem prejuízo da participação que lhe caiba na herança, o direito real de habitação relativamente ao imóvel destinado à residência da família, desde que seja o único daquela natureza a inventariar. (BRASIL, 2002, p.377). 
Em outro caso a lei impede de participar na herança o cônjuge separado judicialmente ou separado de fato há mais de dois anos, salvo a dificílima prova de que a convivência se tornara impossível sem sua culpa, como podemos ver.

Art. 1.830. Somente é reconhecido direito sucessório ao cônjuge sobrevivente se, ao tempo da morte do outro, não estavam separados judicialmente, nem separados de fato há mais de dois anos, salvo prova, neste caso, de que essa convivência se tornara impossível sem culpa do sobrevivente. (BRASIL, 2002, p.377).

Concorrência do cônjuge com descendentes: podemos fundamentar sobre esse tópico importantíssimo a partir do seguinte artigo também do código civil

Art. 1829- A sucessão legítima defere-se na ordem seguinte:

I - aos descendentes, em concorrência com o cônjuge sobrevivente, salvo se casado este com o falecido no regime da comunhão universal, ou no da separação obrigatória de bens (art. 1.640, parágrafo único); ou se, no regime da comunhão parcial, o autor da herança não houver deixado bens particulares(BRASIL, 2002, p.377).

Analisando o inciso I do referido artigo podemos observar que o tema não é muito simples. Ou seja, não é em qualquer hipótese que o cônjuge terá o direito de concorrer com os descendentes do de cujus. Pois cabe saber sobre o regime de bens que regia a relação do casamento. No regime de comunhão universal ou separação obrigatória o cônjuge não terá o direito de concorrer com descendentes do de cujus.

É evidente que na comunhão universal, o cônjuge já recebe por força da meação $50 \%$ de todo o patrimônio do falecido, sendo assim, não seria justo, então, ainda concorrer com os filhos na outra metade. Por sua vez, no regime de separação obrigatória, também é justa a disposição da lei pelas condições de não ter a transferência de patrimônio entre os cônjuges. Na separação convencional e no regime de participação final de aquestos, há direito à concorrência com descendentes.

Um problema muito comum dos regimes ocorre quando observamos as regras relativas à comunhão parcial. Neste regime, o cônjuge só concorrerá com os descendentes na hipótese de o de cujus ter deixado bens particulares. A lei teve a intenção de também flagrar: uma comunhão parcial sem bens particulares significa que todos os bens são "comuns" e, por isso, podemos dizer que estamos diante de um regime de comunhão universal. A metade de tudo que o casal possui, então, já pertence ao cônjuge, por direito próprio de meação, não havendo necessidade de herdar esses bens.

Com essa finalidade os patrimônios do de cujus ficaram pela lei dividida em duas partes: a primeira constituída de bens particulares, excluídos da comunhão. Um típico exemplo de bem particular é o 
adquirido por força de herança, ainda que na constância do casamento. A segunda parte do patrimônio do de cujus é constituída de bens comuns, que correspondem à parte que lhe caiba nos bens amealhados onerosamente na presença do casamento com esforço do casal. Ou seja, quando a esposa viúva concorrer com descendentes, ela disputará a herança justamente na massa patrimonial composta pelos bens particulares e não pelos bens comuns, em que já meou.

Todavia podemos concluir que o art. 1.829, inc. I, só assegura ao cônjuge sobrevivente o direito de concorrência com os descendentes do autor da herança quando casados no regime da separação convencional de bens ou, se casados nos regimes da comunhão parcial ou participação final nos aquestos, o falecido possuísse bens particulares, hipóteses em que a concorrência restringe-se a tais bens, devendo os bens comuns ser partilhados exclusivamente entre os descendentes.

Quotas na concorrência com descendentes: Analisadas as situações em que o cônjuge herdará, passemos às quotas de participação na herança. Concorrendo com os descendentes comuns, a lei preserva o que chamamos de piso da herança é o mínimo de um quarto da herança garantido ao cônjuge, conforme se expõe:

Art. 1832. Em concorrência com os descendentes (art. 1.829, inciso I) caberá ao cônjuge quinhão igual ao dos que sucederem por cabeça, não podendo a sua quota ser inferior à quarta parte da herança, se for ascendente dos herdeiros com que concorrer. (BRASIL, 2002, p.377).

Podemos interpretar dessa forma que havendo mais de três descendentes, e sendo todos comuns, no mínimo, a quarta parte ficará para o cônjuge e o restante será dividido entre os descendentes. Assim, havendo cinco filhos do de cujus concorrendo com o sobrevivente, divide-se o montante em seis partes.

Concorrência com ascendentes: Não existindo descendentes, porém havendo ascendentes, o cônjuge concorrerá independentemente do regime de bens, como podemos ver na lei: “Art. 1.837. Concorrendo com ascendente em primeiro grau, ao cônjuge tocará um terço da herança; caber-lhe-á a metade desta se houver um só ascendente, ou se maior for aquele grau." (BRASIL, 2002, p.378).

No caso de ainda existir pai e mãe do de cujus, a lei reserva ao cônjuge um terço dos bens. Em outra hipótese de ascendentes sendo, por exemplo, apenas avós, metade da herança será destinada ao cônjuge e a outra metade terá como destinatários os ascendentes, sejam quantos existirem.

Vale lembrar uma regra que se refere à sucessão ascendente. Encontrada no seguinte artigo do código civil: 
Institui o Código Civil.

Art. 1.836. Na falta de descendentes, são chamados à sucessão os ascendentes, em concorrência com o cônjuge sobrevivente.

$\S 1$ 1 Na classe dos ascendentes, o grau mais próximo exclui o mais remoto, sem distinção de linhas.

§ 20 Havendo igualdade em grau e diversidade em linha, os ascendentes da linha paterna herdam a metade, cabendo a outra aos da linha materna. (BRASIL, 2002, p.378).

Nessa hipótese, havendo igualdade em grau, por exemplo, $1{ }^{\circ}$ grau: pais, $2 .^{\circ}$ grau: avós, e diversidade na linha materna ou paterna, faz-se a divisão ao meio, entregando metade à linha paterna e metade à linha materna. Lembrando sempre que metade do patrimônio do de cujus já foi entregue ao sobrevivente.

Sucessão do cônjuge inexistindo ascendentes e descendentes: Nessa hipótese, tudo pertence ao cônjuge, independentemente de regime de bens. Em termos simples, o companheiro terá direito à herança dos bens adquiridos na constância da do casamento e a título oneroso.

\section{EXCLUSÃO DO HERDEIRO POR INDIGNIDADE}

\subsection{CONCEITO E FUNDAMENTOS DA INDIGNIDADE}

A definição de indignidade é encontrada em varias obras de autores da área de direito civil em semelhantes definições, neste contexto se ressalta uma posição interessante encontrada no livro do autor Silvio Rodrigues que nas palavras seguintes de Bevilaquia.

Na definição de Bevilaquia, a indignidade é a privação do direito cominada por lei, a quem cometeu certos atos ofensivos à pessoa ou ao interesse do hereditando, ou seja, o legislador cria uma pena, consistente na perda da herança, aplicável ao sucessor legitimo ou testamentário que houver praticado determinados atos de ingratidão contra o de cujus. (RODRIGUES, 2003, p.70).

Ainda em sua obra o autor define a diferença de indignidade e deserção, que são os dois principais meios de exclusão do herdeiro, tópicos muito importantes para área de sucessões, que em suas definições destacam em diferenças detalhadas para dissertação dos fatos. Uma ocorre a partir de um ato imputado como crime doloso e o outro por ato da vontade do autor da herança, a deserção se dá por ato praticado antes da abertura sucessão e a indignidade pode ocorrer tanto antes como depois da abertura da sucessão.

Exclusão por indignidade e deserção, todavia, são institutos paralelos que remedeiam a mesma situação, visto que por intermédio deles se afasta da sucessão o beneficiário ingrato, pois, como observa Lacerda De Almeida, a 
sucessão hereditária assenta na afeição real ou presumida do defunto pelo sucessor, afeição que deve despertar neste ultimo um sentimento de gratidão. A quebra desse dever de gratidão acarreta a perda da sucessão; nisso se combina a indignidade e a deserção. (RODRIGUES, 2003, p. 70).

Ainda no que se diz a diferenciação da indignidade e deserção conceitua a seguinte:

“(...) a indignidade alcança todos os herdeiros: legítimos, necessários, facultativos, testamentários e legatários. A deserdação é restrita aos herdeiros necessários, e só pode ser imposta por testamento, com expressa declaração da causa que motivou o testador a querer privá-los da herança". (DIAS, 2013, p. 298).

Propondo uma visão diferente do assunto neste projeto o autor Silvio De Salvo Venosa vem apresentar as características da indignidade, sendo de grande relevância, pois tais características definem a exclusão do herdeiro. A indignidade é ato reconhecido mediante uma ação de indignidade, prevista no art. 1.185 do Código Civil, qualquer sucessor (seja herdeiro ou legatário) pode ser indigno.

A indignidade exposta na lei não opera automaticamente. Há necessidade que seja proposta uma ação, de rito ordinário, movida por quem tenha interesse na sucessão. $O$ estado esta colocando na posição de herdeiro, de modo que o poder publico esta legitimado a mover a ação contra o indigno, se não houver sucessor mais próximo legitimado a fazê-lo. Seria absolutamente imoral que se permitisse que um filho patricida herdasse do falecido pai, só porque não havia nenhum parente próximo intitulado para afasta-lo da sucessão. (VENOSA, 2001, p.112).

As causas de exclusão por indignidade são as primeiras a serem tratadas pelo Código Civil, estando elencada taxativamente no artigo 1.814 do Código Civil que traz a disposição da lei para com o caso de herdeiro indigno, cada qual que ferir qual quer dos incisos do artigo citado será excluído da herança legalmente e condenado pelos seus respectivos atos, indignos para o de cujus e para com a sociedade.

Art. 1.814. São excluídos da sucessão os herdeiros ou legatários:

I - que houverem sido autores, co-autores ou partícipes de homicídio doloso, ou tentativa deste, contra a pessoa de cuja sucessão se tratar, seu cônjuge, companheiro, ascendente ou descendente;

II - que houverem acusado caluniosamente em juízo o autor da herança ou incorrerem em crime contra a sua honra, ou de seu cônjuge ou companheiro;

III - que, por violência ou meios fraudulentos, inibirem ou obstarem o autor da herança de dispor livremente de seus bens por ato de última vontade. (BRASIL, 2002, p.375).

O termo "indignidade" significa a falta de dignidade, a injuria afrontosa, o demérito. 0 indigno, portanto, é aquele sujeito que se qualifica em consequência da prática de seus atos, baixos, injuriosos ou desrespeitosos em relação aos bons costumes e a outras pessoas. 
Quando ocorrem atos de menosprezo e desapreço, sejam eles atos reprováveis ou delituosos, realizados pelos herdeiros ou legatários em relação ao falecido, os caracterizam como indignos de receber os bens hereditários. Conforme exposto esses fatores podem, assim, ser condensador em atentados contra a vida, contra a honra e a liberdade de testar do de cujus. A esse respeito, conclui: "A indignidade é, portanto, uma sanção civil que acarreta a perda do direito sucessório" (GONÇALVES, 2011, p. 123).

No direito sucessório, a indignidade praticada pelo sucessor o leva à perda do direito subjetivo de herdar, sendo excluído ou afastado da transmissão hereditária.

Portanto, podemos definir a indignidade como a privação do direito hereditário, a quem voluntaria e antijuridicamente cometeu atos tipificados ou atos ofensivos ao de cujus ou a membros de sua família. A despeito disso, conceitua-se: “Instituto bem próximo da incapacidade sucessória é o da exclusão do herdeiro ou do legatário, incurso em falta grave contra autor da herança e pessoas de sua família, que o impede de receber o acervo hereditário, dado que se tornou indigno" (Diniz, 2005, p.50).

Resumindo a indignidade seria a incapacidade particular de suceder em determinada sucessão na qual o herdeiro fosse considerado indigno, mantendo a capacidade nos demais processos sucessórios em que eventualmente pudesse ser chamado. Conforme se aduz:

Aberta a sucessão, a herança é transmitida aos sucessores que tenham legitimidade para tanto. Os que não a tem não adquirem, a qualquer tempo, os bens deixados pelo falecido, ao passo que, nos casos de indignidade, o indigno adquire a herança e a conserva até que passe em julgado a sentença que o exclui da sucessão. (GONÇALVES, 2011, p. 169).

Entretanto, não merece prosperar a ideia de que a indignidade seria uma ilegitimidade, pois o excluído do processo sucessório possui capacidade e legitimação hereditária, mas, por ter sido considerado indigno, é privado do seu direito subjetivo. Ele adquire o acervo, mas é punido posteriormente com a sua perda. Trata-se, portanto, de um impedimento objetivo.

\subsection{CAUSAS DE EXCLUSÃO POR INDIGNIDADE}

Um dos atos mais importantes que pode ser considerado como fundamento do direito sucessório é a transmissão imediata da herança, essa ocorre expressamente aos herdeiros legítimos ou testamentários, desde que possam ser citados para suceder. Essa condição se dá de forma ética levando em consideração seja real ou presumida, portanto, é indispensável que os herdeiros sejam capazes de suceder e não seja excluído da sucessão. 
Essa condição se impõe mediante atos praticados com intuito de coagir ou manipular o autor da herança, fazendo-se assim a repulsa de atos reprováveis e delituosos, o que pode leva-lo a ser considerado indigno de recolher os bens hereditários.

Para que ocorra a exclusão da sucessão hereditária por causa da indignidade são necessários três requisitos: em primeiro lugar, que o herdeiro ou legatário sejam abrangidos pelos casos de indignidade previstos em lei; que o transgressor não tenha sido reabilitado pelo falecido e autor da herança; e que seja proferida uma sentença declaratória de indignidade.

Os atos lesivos que caracterizam a indignidade estão previstos no artigo 1.814, Código Civil. Como já falamos a primeira causa de indignidade se refere à consumação ou à situação de o transgressor tentar ou lesar a vida do hereditando, podendo ser ele o autor, coautor ou partícipe do crime tentado ou consumado.

Em nosso regramento jurídico no que tange ao código civil brasileiro, não é expressa a exigência da sentença condenatória penal, ao que se diz da consequente exclusão do indigno da sucessão, isto ocorre devido à existência da independência da responsabilidade civil no que se refere ao âmbito penal, ou seja, existindo a sentença penal condenatória com efeitos patrimoniais não faz coisa julgada na esfera cível, porém, havendo a sentença penal resultando em absolvição, assim poderá ser concluso o processo excluindo a denominação de indigno quanto à sucessão.

Os fatos que determinam a indignidade dizem respeito a existência de provas quanto a culpabilidade, essas devem ser produzidas no processo civil, para que seja efetuada a exclusão, e caso inexista a culpabilidade a absolvição do acusado deverá ser feita na esfera penal ocorrendo assim o reconhecimento da inexistência do fato e com isso sua inocência.

Incidindo nesta ultima hipótese será afastada a pena de indignidade, podemos comparar tal consideração ao fato de constatação da legítima defesa, quando em estado de necessidade e o mesmo comete um crime de forma a se proteger.

Como já citado acima para configurar causa de exclusão por indignidade o homicídio, tentado ou consumado, deve ser realizado de forma dolosa, com a intenção do resultado. Quando se tratar de homicídio culposo, seja tentado ou consumado, decorrente de negligência, imprudência ou imperícia, não caberá tal exclusão.

Essa definição contribui abundantemente para a área criminal em relação ao herdeiro indigno, pois herdeiro indigno é aquele que perde o direito à sucessão dos bens, que seriam seus por sucessão legal, 
por cometer e ser condenado pelo crime de homicídio do "de cujus" que os possuía. É o caso de um filho que mata o pai, e assim perde o direito à herança. Um exemplo muito famoso de herdeiro indigno é o caso Richthofen.

Neste caso o crime de homicídio doloso, foi consumado a comando da filha Suzane Von Ritchthofen, a indigna teria influenciado seu namorado Daniel a cometer o ato de homicídio contra seus pais, com o objetivo de herdar toda a herança, a mesma nasceu em família rica, e com isso tinha uma ambição e tomar todo o dinheiro da família, a mesma já maior de idade iria ficar sob domínio de todo o dinheiro já que seu irmão mais novo ainda era menor de idade.

Sendo assim, seu namorado Daniel cravinho com a ajuda de seu irmão Cristian cravinhos executaram o ato, dando marretadas no senhor e senhora Richthofen. Após a investigação foi constatado que os irmãos cravinhos assim conhecidos nacionalmente, teriam efetuado o ato, e após muita encenação de Suzane para mídia, a investigação levou ate ela.

Nos últimos anos, o caso mais famoso de perda do direito à herança dos pais é o de Suzane Von Richthofen, condenada por participação, em outubro de 2002, no assassinato dos pais, Mandred e Marísia Von Richthofen, em São Paulo. Suzana, que tinha 18 anos, permitiu a entrada dos executores do crime, os irmãos Cristian e Daniel Cravinhos, na casa da família. Em 2006, Suzane foi condenada a 39 anos de prisão. Em 2011, a 1ạ Vara de Família e Sucessões de Santo Amaro decidiu pela exclusão da condenada da relação de herdeiros, a pedido do irmão, Andreas. Caso o irmão desistisse da ação, segundo a legislação atual, Suzane continuaria tendo direito à metade dos bens. Porém, com as mudanças propostas no PLS 118/2010, o Ministério Público poderia intervir em casos como esse para promover a ação. (AGENCIA SENADO, 2019).

Com no exemplo acima abordado a indignidade se dá pelo crime cometido contra o de cujus conforme já foi citado, esse crime pode ser tanto praticado pelo próprio indigno, quanto por outrem que responda por sua vontade, como no caso de Suzane, que deixou que outros praticassem o crime em seu lugar para assim conseguir receber a herança que lhe era por direito. Como filha a ré do crime em questão se enquadrava como herdeira legatária, de primeiro grau na linha sucessória, tornando-a assim herdeira necessária no direito sucessório.

Como abordado na citação os três réus Suzane Richthofen e Daniel Cravinhos a 39 anos de reclusão e Cristian Cravinhos foi condenado a 38 anos de, pelo assassinato cometido. Suzane foi excluída da herança, conforme o pedido de sue irmão que entrou com uma ação de exclusão, fundamentada na pela legislação brasileira contra aqueles que atentaram contra a vida dos eventuais legadores, conforme já abordamos. 
Como anteriormente falado é direito do irmão de Suzane pedir sua exclusão, mesmo que a mesma foi sentenciada, seria necessário o mesmo fazer tal solicitação, pois, mesmo comprovada a autenticidade criminal, quanto aos de cujus no caso em questão, o Ministério publico, não tem legitimidade para promover a ação de exclusão do herdeiro por indignidade, sendo assim caberá aos seus outros herdeiros propor a mesma.

Dito isto podemos conferir que a partir do ano de 1017 entrou em vigor a seguinte lei, que buscar proporcional tal legitimidade ao ministério publico:

Lei 13.532/2017-

Art.10 Esta Lei confere legitimidade ao Ministério Público para promover ação visando à declaração de indignidade de herdeiro ou legatário, na hipótese que menciona. Art. 20 O art. 1.815 da Lei no 10.406, de 10 de janeiro de 2002 Código Civil, passa a vigorar acrescido do seguinte $\S 2 \circ$, renumerando-se o atual parágrafo único para $\S \quad 1$ 요 $\quad$ "Art. 1.815.

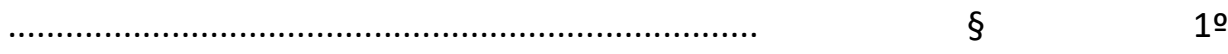

$\S 2$ Na hipótese do inciso I do art. 1.814, o Ministério Público tem legitimidade para demandar a exclusão do herdeiro ou legatário." (Planalto, Lei 13.532/2017, 2020).

Outra causa de exclusão é decorrente da acusação caluniosa realizada em juízo contra o autor da herança, seu cônjuge ou companheiro, ascendente ou descendente, prevista no inciso II, do art. 1.814, do Código Civil. Este tipo de acusação deve ser feita perante juízo criminal para configurar causa de exclusão, sendo assim este gera a exclusão pela a prática de crimes contra a honra do hereditando, de seu cônjuge ou companheiro. Correspondendo aos crimes de calúnia, difamação e injúria.

O inciso III do mesmo artigo diz respeito à vontade do autor da herança e os atos do herdeiro ou legatário que de alguma forma inibir ou obstar tal vontade de se manifestar, configurando a exclusão por indignidade do autor de tal ato. Devemos entender inibir como impedir a ultima vontade, por exemplo, o herdeiro constrange o de cujus a testar. Em relação a atrapalhar, compreende-se em não deixar a vontade de testar, já existente, de se manifestar, por exemplo, o herdeiro impede o testador de revogar testamento anterior. Em ambos os casos os atos atentam contra a liberdade do de cujos de testar.

A declaração de indignidade compõe pena civil que priva o herdeiro do direito de herança, tanto os legatários, quanto os herdeiros necessários que possam ou tenham cometido os atos criminosos ou reprováveis em desfavor do autor da herança, ou seja, a lei estabelece o afastamento do herdeiro indigno e com isso faz um juízo de reprovação, no que se diz à gravidade do ato. É uma forma de punir 
de forma moral e lógica quem pratica atos, sendo estes criminosos de indignidade que de desta forma fique impedido de receber tal beneficio.

O sucessor indigno, é o herdeiro que como abordamos acima, é aquele que pratica atos considerados reprováveis contra o autor da herança na abertura da sucessão, ou como definimos é o indigno, que não é capaz de suceder devido a declaração de indignidade.

Os principais atos de exclusão são taxativamente elencados em lei e estão expostas no artigo 1.814 do Código Civil, que são: atos contra a vida, a honra e a liberdade do de cujus ou de seus familiares. Conforme o mencionado artigo:

Art. 1814. São excluídos da sucessão os herdeiros ou legatários:

I - que houverem sido autores, coautores ou participes de homicídio doloso, ou tentativa desde, contra a pessoa de cuja sucessão se tratar, seu cônjuge, companheiro, ascendente ou descendente.

II - que houverem acusado caluniosamente em juízo o autor da herança ou incorrerem em crime contra a sua honra, ou de seu cônjuge ou companheiro;

III - que, por violência ou meios fraudulentos, inibirem ou obstarem o autor da herança de dispor livremente de seus bens por ato de ultima vontade. (BRASIL, 2002, p.375).

O Sucessor indigno vai ser o autor, coautor ou participe de ato praticado contra a herança do autor, bastando mera participação no crime, para ser excluído da sucessão. Os herdeiros como cônjuge, companheiro, descendente e ascendente do autor da herança também gera indignidade, ou seja, se algum destes atos elencados no artigo acima for praticado contra qualquer um de parentes, o sucessor que o fez poderá se tornar indigno.

O inciso segundo do mencionado artigo dispõe que a denunciação caluniosa do de cujus em juízo ou a prática de crime contra sua honra, pode ser caracterizado como atos de indignidade. Ou seja, caracteriza-se crime de denunciação caluniosa, quando o autor da denuncia que instaurou a investigação policial, processo judicial, instauração de investigação administrativa, inquérito civil ou ação de improbidade administrativa contra alguém, imputando-Ihe crime que o mesmo seja inocente.

Em resumo a causa anterior pode se dizer que aquele herdeiro que agir de má fé caluniando o autor da herança de forma em que o mesmo responda judicialmente, mesmo sendo inocente, poderá ser excluído da herança, pelo ato reprovável.

Em rega esta acusação deve ser feita mediante a polícia, ou outra repartição pública, e ainda que seja veiculada em juízo criminal, mediante formulação de queixa-crime ou de representação ao Ministério Público, para desta forma ferir a honra e a dignidade do autor da herança configurando assim 
indignidade do herdeiro que gerou a acusação caluniosamente. Isto ocorre, pois se o mesmo fosse feito perante o juízo civil não poderia se caracterizar como indignidade.

A pratica de crimes contra a honra do hereditando encontra-se elencadas nos artigos expostos abaixo, que se trata de calunia difamação e injuria.

Artigo 138, - Caluniar alguém, imputando-Ihe falsamente fato definido como crime.

Artigo 139, - Difamar alguém, imputando-lhe fato ofensivo à sua reputação.

Artigo 140, Injuriar alguém, ofendendo the a dignidade ou o decoro. (BRASIL, Código Penal - 1940). (Brasil, Código Penal, p.56)

Os crimes citados e expostos acima assim que são em desfavor da honra precisam de ação condenatória, visto que se refere a herdeiros que praticaram crimes contra a honra do de cujus, sendo assim, pode-se concluir que o reconhecimento da indignidade, nas hipóteses mencionadas acima dependem de condenação criminal.

A terceira categoria dos indignos constata atos contra a liberdade do autor da herança. Se alguém por violência ou meios criminosos obstar que a liberdade da pessoa seja inferida, pratica atos contra a liberdade do falecido. A violência entende-se tanto física, moral ou psicológica.

Sendo assim conforme expõe o artigo seguinte: “Art. 1.815. A exclusão do herdeiro ou legatário, em qualquer desses casos de indignidade, será declarada por sentença." (BRASIL, 2002, p.375).

Portanto a mesma depende da propositura da ação especifica, do interessado para que assim possa ser dada uma sentença. No que depreende desta temática, a ação não pode ser proposta pelo hereditando sendo assim aduz: "A ação para a exclusão do indigno não pode ser proposta em vida, mas somente após a morte do hereditando, pois ate então inexiste a sucessão: herditas viventis non datur". (Pereira, 2010, p.35).

Tendo como objetivo a prevenção como uma garantia esse dispositivo busca garantir a plena liberdade ao de cujos de dispor seu testamento. Preceitua o código civil sobre essa referida causa de indignidade, com a finalidade de defender a liberdade do de cujos de testar, sendo consequência ao herdeiro que, que pratica atos criminosos de forma, dolosa ou coativamente, atentando contra essa liberdade de forma a impedir ou confundir o de cujos em seu ato de última vontade.

\subsection{AÇÃO DECLARATÓRIA DE INDIGNIDADE}

Para existir a definição jurídica e a decorrente exclusão do herdeiro por indignidade deve se existir a ação declaratória de indignidade, a mesma consiste em uma ação de rito ordinário, onde o 
determinado herdeiro que será classificado como indigno tem a chance de apresentar defesa, isto acontece, pois a lei busca não ferir o princípio da presunção de inocência.

Em vista disso proclama o artigo 1815 do código civil que a exclusão do herdeiro ou legatário, em qualquer desses casos de indignidade, será declarada por sentença.

Art. 1.815. A exclusão do herdeiro ou legatário, em qualquer desses casos de indignidade, será declarada por sentença.

$\S 100$ direito de demandar a exclusão do herdeiro ou legatário extingue-se em quatro anos, contados da abertura da sucessão.

$\S 20$ Na hipótese do inciso I do art. 1.814, o Ministério Público tem legitimidade para demandar a exclusão do herdeiro ou legatário. (BRASIL, 2002, p.375).

Embasado nesta determinação interpretamos que os coautores conforme expressam no inciso I do artigo 1814. Ou participes do homicídio doloso, se comprometerão assim sendo punidos, de forma a serem excluídos por indignidade da herança do referido falecido e vitima do ato indigno.

O crime de homicídio doloso expresso acima deverá ser doloso, ou seja, deverá ser comprovada a intenção de matar, se o mesmo for provado culposo, não há o que se falar em exclusão por indignidade.

Outro fato que pode o liberar o indigno desta nomeação é sua absolvição, sendo este absolvido na esfera penal, o mesmo será reconhecido como legitimo, ou seja, digno da herança, e poderá herdar. Conforme se aduz o art. 935 do código civil:

Art. 935. A responsabilidade civil é independente da criminal, não se podendo questionar mais sobre a existência do fato, ou sobre quem seja o seu autor, quando estas questões se acharem decididas no juízo criminal. (BRASIL, 2002, p.247).

Sendo assim o mesmo será isento dos fatos, terá o expresso reconhecimento da inexistência do fato.

Por esses fundamentos, pode se concluir que não basta a simples prática contra a lei que leva o herdeiro ou legatário a ser excluído, depende de reconhecimento da causa da indignidade em sentença proferida em ação própria.

Conforme já abordado anteriormente o indigno terá que ser sentenciado pelas praticas impostas no artigo 1814, do código civil, ainda que tenha praticado o ato mais grave dos mencionados no artigo anterior e que enseja maior repulsa, qual seja o homicídio doloso, o herdeiro não será excluído da sucessão automaticamente, senão mediante ação declaratória intentada com o objetivo de excluí-lo por decisão judicial. 
A Ação Declaratória de Indignidade é uma ação onde o herdeiro indigno tem a chance de apresentar sua defesa, por conta disso não há o que se falar aqui em princípio da presunção de inocência.

Como o próprio nome já diz, ela tem natureza declaratória, qual seja a de consolidar uma situação jurídica já existente que é a pratica de um crime contra a pessoa do autor da herança.

Quanto ao legítimo interesse para o ajuizamento da ação de exclusão do indigno, podemos classificalo como direito privado, e não público só aquele que se beneficiar com a sucessão poderia propor a exclusão do indigno. Como no exemplo a seguir

Sendo dois irmãos os herdeiros, se um for excluído da sucessão, o outro recebe toda herança. Assim, há interesse na exclusão da sucessão. Por outro lado, se o excluído da sucessão tiver filhos, o irmão não tem interesse na propositura da ação, pois os beneficiados são os filhos do indigno ou deserdado que herdam por representação.

(CONJUR,2020).

Portanto, mesmo que exista uma ação de exclusão seus sucessores irão suceder. Dessa forma, se o herdeiro seja ele legítimo ou testamentário assassinou o hereditando, mas as pessoas a quem sua exclusão se beneficiaria preferissem manter-se em silencio o assassino não perderia a condição de herdeiro e receberia bens da herança, não podendo a sociedade, através do Ministério Público, impedir tal solução. "Não consta expressamente que a exclusão por indignidade deve ser movida por quem tenha interesse na sucessão, nem especifica o rito a ser seguido, \{...\} Para propor ou contestar a ação é necessário ter interesse e legitimidade". (GONÇALVES, 2011, p.96).

Em resumo, se não for um herdeiro legatário ou necessário a solicitar a exclusão do indigno, mesmo que a esse exista uma investigação criminal, o Ministério publico, não o poderá considerar indigno ou o proibir de receber ou concorrer a herança, na abertura da sucessão.

A Ação Declaratória de Indignidade deve ser proposta no prazo máximo de quatro anos contados a partir da abertura da sucessão, passados os quatro anos ocorrem à decadência do direito de demandar a indignidade.

O prazo de quatro anos traçado pela lei é decadencial, já que o direito de requerer a exclusão do indigno, que nasce para o interessado no momento da abertura da sucessão, é o direito potestativo que a lei assegura, e é sabido que os direitos potestativos sujeitam sempre a prazos decadenciais para seu exercício. (HIRONAKA, 2018, p. 37).

Portanto, o herdeiro que quiser solicitar a exclusão do suposto indigno na abertura da sucessão deverá solicitar a ação no determinado prazo. 


\subsection{EFEITOS DA EXCLUSÃO POR INDIGNIDADE}

O herdeiro não será excluído pela indignidade senão por sentença declaratória de maneira exclusiva, ou seja, o efeito da indignidade é pessoal.

O seguinte artigo expõe: “Art. 1.816. São pessoais os efeitos da exclusão; os descendentes do herdeiro excluído sucedem, como se ele morto fosse antes da abertura da sucessão". (BRASIL, 2002, p.375).

Sendo assim o mesmo artigo, expressa que o herdeiro excluído pela indignidade será considerado como se morto fosse antes da abertura da sucessão, portanto caberá o seu quinhão aos seus descendentes.

Se os descendentes forem incapazes, o herdeiro indigno não poderá ser o administrador nem terá direito ao usufruto, como está escrito no parágrafo único do artigo 1.816 do Código Civil: "Parágrafo único. O excluído da sucessão não terá direito ao usufruto ou à administração dos bens que a seus sucessores couberem na herança, nem à sucessão eventual desses bens." (BRASIL, 2002, p.375).

Dos bens que couberem a seus sucessores visto que a natureza jurídica da indignidade é de ser uma pena, não é considerado justo que aquele declarado indigno em decorrência de um fato imprevisível venha a ter acesso aos bens que não é considerado merecedor.

Em relação aos demais herdeiros, a sentença declaratória de indignidade tem efeito "ex tunc", isto é, retroage a data da abertura da sucessão, portanto, como já discorrido a cima, serão chamados a suceder os herdeiros do indigno, pois estes não cometeram atos considerados ofensivos.

Os herdeiros que substituírem o herdeiro indigno podem requerer perdas e danos sempre que constatarem prejuízo em razão da má administração do sucessor excluído feita antes da sentença declaratória, como demonstra o artigo 1.817 do Código Civil:

Art. 1.817. São válidas as alienações onerosas de bens hereditários a terceiros de boa-fé, e os atos de administração legalmente praticados pelo herdeiro, antes da sentença de exclusão; mas aos herdeiros subsiste, quando prejudicados, o direito de demandar-Ihe perdas e danos. (BRASIL, 2002, p.375).

Podemos notar outro efeito encontrado também no artigo 1.817, no seu parágrafo único como se explana abaixo:

Parágrafo único. $O$ excluído da sucessão é obrigado a restituir os frutos e rendimentos que dos bens da herança houver percebido, mas tem direito a ser indenizado das despesas com a conservação deles. (BRASIL, 2002, p.375). 
Portanto, é importante frisar que os sucessores que vierem a se beneficiar da exclusão do indigno, fazem jus aos frutos e rendimentos que os bens produziram a época em que estiveram sob o cuidado do indigno.

Vale lembrar que o herdeiro indigno tem direito a indenização sobre as despesas empreendidas para a conservação dos bens, caso não haja indenização, configura-se o enriquecimento sem causa dos sucessores do indigno.

Em relação aos sucessores do indigno, aponta o seguinte artigo apresentado pelo senado disponível no site do IBDFAM (Instituto Brasileiro de Direito de Família) na matéria titulada "descendentes de herdeiro indigno também podem ser proibidos de receber bens", entra no seguinte tópico onde os herdeiros hereditários, que no caso seriam os sucessores do herdeiro indigno, também por consequência se tornariam indignos.

O relator da matéria na CCJ, senador Flexa Ribeiro (PSDB-PA), deu parecer favorável à matéria com uma emenda: o descendente do indigno também herdeiro ou legatário do autor da herança por direito próprio, herdará somente a sua parte; não o sendo, será excluído da herança. “O entendimento contrário não apenas privaria o filho do herdeiro indigno da legítima herança, bem como faria com que a 'pena' do herdeiro indigno fosse transferida para os seus filhos", justificou o relator. (IBDFAM, Ministério Público, 2019).

No entanto conforme disposto ainda no mesmo, a lei ainda não alcança esses excluídos e ainda permite a transferência imediata aos descendentes do indigno. Ou seja, mesmo que sejam descendentes do indigno receberiam suas respectivas cotas da parte da herança mesmo que o indigno seja excluído.

Quando se trata de aquisição de bem por terceiro de boa-fé a título oneroso, o negócio jurídico não poderá ser desfeito.

Essa determinação legal como aborda o artigo citado anteriormente, protege e privilegia a boa-fé daquele que, pensando ser o indigno realmente o herdeiro, efetua um negócio jurídico no sentido de este seja válido.

Dessa forma, preservado o negócio jurídico oneroso realizado sob a égide da boa-fé, poderão os sucessores prejudicados intentar perdas e danos em face do sucessor indigno.

Ocorrendo o reconhecimento judicial da indignidade ocorrerão os seguintes efeitos: O indigno será excluído da sucessão, sendo os efeitos deste pessoal, cabendo aos seus descendentes o recebimento por extirpe em seu lugar, pois se dá como se morto fosse ele no momento da sucessão. 
Quando proferida a sentença, seus efeitos retroagem à data da abertura da sucessão, em outras palavras, a decisão judicial possui aplicação ex tunc.

Em relação ao usufruto e à administração dos bens herdados pelos sucessores do indigno, a lei o proíbe de gozar desses, uma vez que ele indiretamente estaria se beneficiando de algo que lhe foi afastado pelas causas de indignidade, confirmada pela sentença que a declarou, não podendo, assim, por ordem de vocação hereditária receber tais bens quando seus descendentes morrerem em momento anterior a ele. Ou seja, sendo o herdeiro indigno e não havendo sucessores deste, o mesmo não terá vocação hereditária para herdar.

\subsection{A REABILITAÇÃO OU PERDÃO DO INDIGNO}

O autor da herança, tendo conhecimento que seu sucessor ou legatário cometeu um ato que caracteriza a indignidade, pode reabilitá-lo, desde que seja feito de forma expressa. Esse perdão pode ser concedido por meio de um ato autêntico ou por intermédio de um testamento.

De acordo com o código civil em seu art. 1.818, parágrafo único, se o testador contemplar o indigno em seu testamento, quando já tinha conhecimento da causa de indignidade, este poderá sucedê-lo no limite da disposição testamentária, ocorrendo, assim, uma reabilitação não expressa.

Art. 1.818. Aquele que incorreu em atos que determinem a exclusão da herança será admitido a suceder, se o ofendido o tiver expressamente reabilitado em testamento, ou em outro ato autêntico.

Parágrafo único. Não havendo reabilitação expressa, o indigno, contemplado em testamento do ofendido, quando o testador, ao testar, já conhecia a causa da indignidade, pode suceder no limite da disposição testamentária. (BRASIL, 2002, p.375).

Deste modo, é considerável registrar que a indignidade não é absoluta, sendo provável a reabilitação do indigno, conforme mencionado. De acordo com o artigo supramencionado, aquele que incorreu em atos que determinem a exclusão da herança será admitido a suceder, se o ofendido o tiver expressamente reabilitado em testamento, ou em outro ato autêntico. Ou seja, se mesmo ciente do ato indigno o falecido deixar em testamento herança para o referido herdeiro o mesmo será considerado assim de forma expressa sendo assim reabilitado para suceder. "O herdeiro que incorreu em indignidade poderá ser perdoado pelo ofendido, porque ninguém melhor do que ele para avaliar o grau da ofensa sofrida." (DINIZ, 2018, p. 45).

Não podendo, de forma alguma, ser concedido o perdão de maneira tácita, é um ato caracterizado por sua irretratabilidade, ou seja, uma vez reabilitado o indigno, assim fixará. 
A reabilitação é um instituto jurídico que implica no perdão da indignidade, e permite ao indigno a possibilidade de suceder novamente no testamento. Todavia, tal instituto somente é aceito se houver manifestação expressa, seja no testamento, seja em qualquer ato autêntico.

Pode se concluir sobre essa afirmação baseando-se na seguinte: "Uma vez concedido o perdão, este será irretratável, não mais se reconhecendo aos coerdeiros legitimação para reabrir o debate." (DINIZ, 2018, p. 57).

Outra previsão legal que podemos dar fundamento a este evento se encontra no seguinte: “Art. 1.818. Aquele que incorreu em atos que determinem a exclusão da herança será admitido a suceder, se o ofendido o tiver expressamente reabilitado em testamento, ou em outro ato autêntico." (BRASIL, 2002, p.375).

Nesta condição, caso o autor da herança, através de testamento ou documento autêntico, reabilite o indigno, a exclusão do herdeiro ou legatário ficará prejudicada.

A reabilitação poderá ser tácita, nos termos do parágrafo único do dispositivo legal supracitado como podemos ver abaixo: "Parágrafo único. Não havendo reabilitação expressa, o indigno, contemplado em testamento do ofendido, quando o testador, ao testar, já conhecia a causa da indignidade, pode suceder no limite da disposição testamentária." (BRASIL, 2002, p.375).

Se após a ofensa houver o testador contemplado o agente em testamento, estando ciente da causa de sua indignidade, o indigno poderá suceder nos limites da disposição testamentária.

A reabilitação é irretratável, uma vez declarada, será fixa mesmo que tenha sido revogada ou se tenha tornado impossível. Nos que diz o seguinte autor quanto à irrevogabilidade da reabilitação: “Uma vez concedido torna-se irretratável, sob pena de tolerar-se arrependimento no perdão, o que não seria moral. Deste modo, mesmo revogado o testamento que contém o perdão, permanece válido a cláusula que reabilita o indigno." (GONÇALVES, 2017, p. 64).

Contudo, a mesma é passível de impugnação por vício de vontade: erro, dolo ou coação. Sendo cientificada antes do óbito do autor da sucessão, não importa a capacidade sucessória do incurso em indignidade. Se caso após a declaração judicial da indignidade for localizado algum documento que contenha a reabilitação, o indigno recupera a capacidade sucessória, tornando sem efeito a exclusão. O perdão é o ato em que o autor da herança, de forma expressa, mediante declaração no testamento ou por meio de qualquer outro documento, público ou particular, perdoa o herdeiro indigno, fazendo, assim, com que ele tenha direito à herança. 
É admitido ainda, o perdão tácito, no caso, por exemplo, de o autor da herança ter contemplado o indigno em seu testamento mesmo após a ofensa. $\mathrm{O}$ ato do autor da herança expressa desta forma o perdão do indigno, caso seja comprovado algum tipo de coação ou dolo, o perdão poderá ser invalidado.

Sobre o perdão temos fundamento o que se expressa no seguinte:

O perdão é, portanto, ato solene, pois a lei só lhe dá eficácia se efetuado mediante ato autentico, ou em testamento. Deve ser expresso, embora não exijam palavras sacramentais. Uma vez concedido torna-se irretratável, sob pena de tolerar-se arrependimento no perdão, o que não será moral. (GONÇALVES, 2011, p. 87).

Em finalidade quanto o que se explana das formas de reabilitação ou perdão do indigno, pode se concluir que as mesmas devem ser feitas legalmente e de forma expressa para a validação do direito de suceder novamente no que se diz respeito ao determinado herdeiro indigno.

No caso citado da Indigna Suzane Von Richthofen, mesmo cometido o assassinato de seus pais, teve o expresso perdão por parte de seu irmão, ainda cumprindo pena, ele diz o seguinte:

"Perdoar é abrir o coração. Não só perdoei minha irmã Su, mas continuo a amála. Agora, principalmente, é o momento em que ela mais precisa do amor. Apesar da dor, tenho plena certeza de que nossos pais a perdoaram. Ainda ontem ouvi uma frase que muito me marcou: a humanidade deve caminhar unida em busca da civilização do amor". (FOLHA ONLINE, 2020.).

Tanto no caso testamentário ou das sucessões, como desenvolvemos, é necessário o perdão, porém no caso da reabilitação social, o perdão é designado aos outros herdeiros vivos, que podem ou não perdoar, não sendo este de forma tácita nem jurídica, muito menos obrigatória.

\subsection{O PRINCÍPIO DA PRESUNÇÃO DE INOCÊNCIA E O PRINCÍPIO DO CONTRADITÓRIO}

O principio da presunção da inocência visa garantir a liberdade do acusado e é determinado constitucionalmente. A presunção de inocência é uma das mais importantes garantias constitucionais, pois por meio dela o acusado passa a ser sujeito de direitos dentro da relação processual é um dos princípios que visam a tutela da liberdade pessoal

Conforme a constituição estabelece o principio da presunção de inocência de conceitua a partir do artigo 5, inciso "LVII - ninguém será considerado culpado até o trânsito em julgado de sentença penal condenatória;". (BRASIL, Constituição federal, 1988, p. 16).

Portanto a presunção da inocência não é apenas mais um principio é um direito garantido, que funciona conforme o seguinte: 
Se o réu é inocente até que a decisão condenatória se torne definitiva, não seria possível fazê-lo cumprir antecipadamente a pena. Ocorre que os direitos e garantias fundamentais, previstos na Constituição, servem para proteção do indivíduo, e não para prejudicá-lo, o que aconteceria caso fosse invocada a presunção de inocência como causa impeditiva da execução provisória. (Nucci, 2020, p. 563)

A presunção de inocência é na verdade um estado de inocência, logo, o acusado é inocente durante o processo e seu estado só se modificará com a declaração de culpado por sentença.

“(...) a presunção de inocência exige uma proteção contra a publicidade abusiva e a estigmatizarão (precoce) do réu. Significa dizer que a presunção da inocência (e também as garantias constitucionais da imagem, dignidade e privacidade) deve ser utilizada como verdadeiro limite democrático a abusiva exploração midiática em torno do fato criminoso e do próprio processo judicial. O bizarro espetáculo montado pelo julgamento midiático deve ser coibido pela eficácia da presunção de inocência" (LOPES JUNIOR, 2012, p. 778).

Há o que se falar sobre a necessidade da condenação para que se determine culpado, porém em outras vias se definem de forma diferente.

A doutrina discute se é necessário que o preso seja condenado definitivamente pelo novo crime para a decretação da regressão, em homenagem ao princípio da presunção de inocência. Entretanto, o STJ entende não ser necessária a condenação definitiva, conforme se verifica na Súmula 526, que dispõe que o reconhecimento de falta grave decorrente do cometimento de fato definido como crime doloso no cumprimento da pena prescinde do trânsito em julgado de sentença penal condenatória no processo penal instaurado para apuração do fato. (NOVAES, 2020, p.82).

Ainda que doutrinadores e julgadores interpretem de forma diferente o que prevalece é a eficácia constitucional do direito e garantia.

Um dos maiores enfrentamentos que vemos na atualidade quanto a unidade processual, envolvendo competências originárias nos tribunais superiores, é a regra insculpida na Súmula 704 do STF e a disposição do Pacto de San José da Costa Rica, referente ao duplo grau de jurisdição. Vejamos:

Súmula 704 do STF: Não viola as garantias do juiz natural, da ampla defesa e do devido processo legal a atração por continência ou conexão do processo do corréu ao foro por prerrogativa de função de um dos denunciados.

Vs.

Art. 8. Pacto San José da Costa Rica - Garantias judiciais:

2. Toda pessoa acusada de um delito tem direito a que se presuma sua inocência, enquanto não for legalmente comprovada sua culpa. Durante o processo, toda pessoa tem direito, em plena igualdade, às seguintes garantias mínimas: (...)

h) direito de recorrer da sentença a juiz ou tribunal superior. (NOVAES, 2020, p. 136). 
Quanto ao princípio do contraditório pode se dizer que se qualifica como um dos principais fundamentos no âmbito criminal, logo após o princípio da presunção de inocência. "O também garantido na Constituição federal se encontra no art. 5ㅇ, inciso LV “ aos litigantes, em processo judicial ou administrativo, e aos acusados em geral são assegurados o contraditório e ampla defesa, com os meios e recursos a ela inerentes" (BRASIL, 1988, p.16).

Na pratica este princípio tem o mesmo efeito processual do princípio anterior, prezando pela inocência do acusado até que se prove o contrário.

“Deve-se assegurar ao agente, mesmo que comprovada sua inimputabilidade, o direito à ampla defesa e ao contraditório. Somente após o devido trâmite processual, com a produção de provas, poderá o juiz, constatando a prática do injusto, aplicar-lhe medida de segurança." (Nucci, 2020, p. 767).

O seguinte artigo explica de forma clara seu conceito e aplicações:

"Na definição de Canuto Mendes de Almeida, é "a ciência bilateral dos atos e termos processuais e possibilidade de contrariá-los", pelo que representa uma garantia conferida às partes de que elas efetivamente participarão da formação da convicção do juiz. De certa forma, pode ser dito, como bem lembra a melhor doutrina, que encontra-se inserido no conjunto das garantias que constituem o princípio do devido processo legal.

Em linhas gerais, pode ser dito que o princípio do contraditório significa que cada ato praticado durante o processo seja resultante da participação ativa das partes. Surge como uma garantia de justiça para as partes e tem, como ponto de partida, o brocardo romano audiatur et altera pars - a parte contrária também deve ser ouvida. É de suma importância que o juiz, antes de proferir cada decisão, proceda a devida oitiva das partes, proporcionando-lhes a igual oportunidade para que, na forma devida, se manifestem com os devidos argumentos e contraargumentos. Também, não pode deixar de ser lembrado que o juiz, ao prolatar a sentença, deve oferecer, aos litigantes, a oportunidade para que busquem, pela via da correta argumentação, ou em conjunto com os elementos de prova colhidos, se assim for o caso, influenciar na formação de sua convicção.

Como pode ser constatado, os direitos ao contraditório, e também à ampla defesa, são devidamente viabilizados pela exigência legal de se dar ciência dos atos praticados aos litigantes, a qual, a seu turno, advém do direito de informação previsto no art. 5ㅇ, XIV, da CF. Tal ciência, cabe lembrar, é feita através dos chamados atos de comunicação: citação, intimação e notificação.

Em resumo, pode ser dito que o princípio do contraditório é constituído por dois elementos, a saber: informação e possibilidade de reação. 
Também, cabe enfatizar que nossa Constituição de 1988 autorizou o entendimento de que os princípios do contraditório e da ampla defesa sejam garantidos no processo administrativo, inclusive não punitivos, em que não existem acusados, mas litigantes, ou seja, titulares de interesses conflitantes." (CARNEIRO, 2020)

Em suma o principio do contraditório é a possibilidade de se defender da acusação que lhe cabe, em regra esse principio visa a garantir, que as duas partes de um processo sejam ouvidas e tenham as mesmas oportunidades e instrumentos para fazer valer seus direitos e pretensões.

\subsection{A NECESSIDADE DA SENTENÇA CONDENATÓRIA}

Como dissertado nos tópicos anteriores, pudemos analisar as causas de exclusão de herdeiro por indignidade tal como os efeitos de tal exclusão, porém, para uma melhor compreensão é necessária a abordagem no que tange, a necessidade de uma sentença penal condenatória antes do julgamento cível, analisando o princípio constitucional da presunção de inocência, vejamos:

Art. 5o Todos são iguais perante a lei, sem distinção de qualquer natureza, garantindo-se aos brasileiros e aos estrangeiros residentes no País a inviolabilidade do direito à vida, à liberdade, à igualdade, à segurança e à propriedade, nos termos seguintes:

[...] LVII - ninguém será considerado culpado até o trânsito em julgado de sentença penal condenatória; [...] (BRASIL, 1988, p.16).

Neste sentido, uma vez que, a carta magna estabelece que ninguém será considerado culpado até o trânsito em julgado através de uma ação penal condenatória, como tal princípio constitucional afeta no julgamento cível do herdeiro por indignidade, vejamos:

Art. 1.814. São excluídos da sucessão os herdeiros ou legatários:

I - que houverem sido autores, co-autores ou partícipes de homicídio doloso, ou tentativa deste, contra a pessoa de cuja sucessão se tratar, seu cônjuge, companheiro, ascendente ou descendente;

II - que houverem acusado caluniosamente em juízo o autor da herança ou incorrerem em crime contra a sua honra, ou de seu cônjuge ou companheiro; (BRASIL, 2002, p.375).

Nos dois primeiros incisos acima, a jurisprudência afirma categoricamente que é necessário que se aguarde o trânsito em julgado, neste sentido, Tartuce nos diz que:

A respeito dos crimes mencionados nos incisos I e II do comando em questão, há necessidade do trânsito em julgado da sentença penal condenatória. Além disso, essa sentença penal condenatória, por si só, não tem o condão de excluir o herdeiro, sendo necessária a ação de indignidade tratada no antes citado art. 1.815 do Código Civil. Como leciona Maria Helena Diniz, "a exclusão do herdeiro pela prática de um dos atos do art. 1.814 não se opera ipso iure. Imprescindível será o pronunciamento da indignidade por sentença proferida em ação 
ordinária (por ser matéria de alta indagação), movida, dentro do prazo decadencial de quatro anos, contado da abertura da sucessão, contra o herdeiro que praticou ato passível de excluí-lo da herança por quem tenha legítimo interesse na sucessão, isto é, coerdeiro, legatário, donatário, fisco, ou melhor, o Município, o Distrito Federal ou a União, inexistindo herdeiro legítimo ou testamentário, e qualquer credor prejudicado com a inércia desses interessados, ou, então, o Ministério Público, diante da omissão legal, por ser guardião da ordem jurídica (CF, art. 127) e por haver interesse público e social de que o herdeiro desnaturado venha a receber a fortuna do auctor sucessionis, que foi, por ele, ofendido" (DINIZ, 2010, p. 1.287). (TARTUCE, 2019, p. 96).

Neste sentido, não pairam duvidas que no caso de pratica de dos crimes previstos nos incisos I e II do artigo 1.814 do Código Civil, é necessário que haja a condenação criminal, porém, mesmo após a sentença é necessário que seja ajuizada a competente ação cível para que tal herdeiro seja declarado indigno com nos traz o artigo 1.815 do Código Civil, vejamos:

Art. 1.815. A exclusão do herdeiro ou legatário, em qualquer desses casos de indignidade, será declarada por sentença.

$\S 1$ o 0 direito de demandar a exclusão do herdeiro ou legatário extingue-se em quatro anos, contados da abertura da sucessão.

$\S 2$ o Na hipótese do inciso I do art. 1.814, o Ministério Público tem legitimidade para demandar a exclusão do herdeiro ou legatário. (BRASIL, 2002, p.375).

Contrariando o entendimento do doutrinador Flávio Tartuce, o doutrinador Cláudio Luiz Bueno enfatiza que não há a necessidade de condenação criminal mês tratando-se do artigo 1.814 incisos I e II, vejamos:

Hipóteses- inciso 1: o primeiro caso de indignidade é o do sucessor que tiver sido autor, coautor ou participe de homicídio doloso, consumado ou tentado, contra o autor da herança, seu cônjuge, companheiro, ascendente ou descendente. Não importa se matou visando à herança. $\mathrm{O}$ atual Código traz como novidade a inclusão

desses familiares próximos do autor da herança, pois o de 1916 só fazia menção ao de cujus. Ao se referir a homicídio doloso, a lei exclui propositalmente o culposo, pois o repúdio da lei é ao atentado intencional contra a vida do autor da herança. Pela mesma razão deve ser excluído o homicídio preterdoloso, em que o resultado morte advém de culpa, não de dolo. Dispensa-se condenação criminal, consoante entendimento tranquilo. Nem se suspende o processo civil, que vis.1 à declaração de indignidade, para aguardar solução do processo crime. A absolvição criminal pode influenciar a decisão no juízo cível, por exemplo, se tem por fundamento a inexistência de crime. Para a exclusão, basta que o sucessor seja partícipe. A legítima defesa e o estado de necessidade excluem o crime e, portanto, a indignidade. Também não é justificada a aplicação da indignidade nos casos de erro de execução. 10, quando atingida a pessoa que não se visava a matar; sendo considerado, para fins penais, como se houvesse sido assassinada a pessoa visada (arts. $20, \S 3^{\circ}$, e 73 , do CP). (GODOY, 2018, p. 196). 
Percebe-se, que o legislador, preocupou-se, bastante com a severidade das consequências caso o herdeiro pratique algo contra seu antecessor, deixando à baila a discussão sobre a necessidade da condenação criminal nos casos tipificados no artigo 1.814, incisos I e II, porém, há de se ressaltar, que o rigor a se recair contra o herdeiro mesmo tendo sido absolvido no processo criminal em alguns casos, vejamos:

\begin{abstract}
Em relação aos penalmente inimputáveis, Orlando Gomes afirma que não estão sujeitos à pena por indignidade (Sucessões, 12. ed. Rio de Janeiro, Forense, 2004, p. 34). No entanto, Sílvio de Salvo Venosa sustenta que o sentido ético da exclusão por indignidade se sobrepõe ao conceito legal de inimputabilidade, não sendo moralmente defensável o recebimento da herança pelo adolescente que comete ato i11fracional consistente, por exemplo, em homicídio doloso do de cujus (Direito civil, 3. ed. São Paulo, Atlas, 2003, v. VII, p. 82). Uma vez que há crime, mas o agente não está sujeito a sanção penal, talvez a melhor solução seja considerar subsistente a sanção civil, que é um min11s, quando remanesce algum grau de discernimento, fazendo-se avaliação caso a caso, orientação que parece mais adequada à disciplina do Estatuto da Pessoa com Deficiência, Lei n. $13.146 / 2015$. (GODOY, 2018, p. 206).
\end{abstract}

Portanto, quando tratar-se dos crimes elencados no Inciso I do artigo 1.814, há de se ter cautela, porém, entende-se que para o direito sucessório a vontade do legislador foi de uma maior independência da ação cível, visando uma maior proteção ao patrimônio e demais herdeiros contra o filho indigno "que houverem sido autores, co-autores ou partícipes de homicídio doloso, ou tentativa deste, contra a pessoa de cuja sucessão se tratar, seu cônjuge, companheiro, ascendente ou descendente" (BRASIL, 2002, p.375).

No que tange ao inciso III do artigo 1.814 aqui tratado, o doutrinador Flávio Tortuce defende que:

No que diz respeito ao inciso III do art. 1.814 do Código Civil, cabe pontuar que a hipótese trata de violência ou fraude à vontade do autor da herança. A violência deve ser tida em sentido amplo, englobando tanto a física quanto a psicológica. Já o termo fraude deve ser entendido como qualquer atuação que burle a vontade do falecido, inclusive as praticadas em abuso de confiança. Nos dizeres de Eduardo de Oliveira

Leite, "a liberdade é a tônica da disposição do patrimônio causa mortis e, por isso, a lei pune 'o que atenta contra ele, por violência ou dolo, coação ou artifício; não só quando impede a feitura do instrumento, ou consegue alterar o que estava pronto, como abusar da confiança do testador, exercer pressão sobre ele, iludi-lo, fazer maliciosamente, crer em fatos não reais; mas também quando oculta, vicia, inutiliza, falsifica o escrito revelador das disposições derradeiras do de cujus, ou embaraça o cumprimento das mesmas'" (Comentários..., 2003, v. XXI, p. 162). Em todos os casos, cabe ao interessado construir a efetiva prova do enquadramento na previsão legal, conforme bem se posiciona a jurisprudência (TJSP, Apelação 0005860- 57.2009.8.26.0457, Acórdão 
6894304, 7.a Câmara de Direito Privado, Pirassununga, Rel. Des. Luiz Antonio Costa, j. 31.07.2013, DJESP 08.08.2013).

Expostas as hipóteses de indignidade, surge, mais uma vez, a seguinte dúvida, tão comum na realidade do Direito Civil contemporâneo: o rol do art. 1.814 do Código Civil é taxativo (numerus clausus) ou exemplificativo (numerus apertus)? Existem argumentos consideráveis - geralmente utilizados por este autor para defender suas teses - para as duas correntes. Para a afirmação de que o rol é taxativo, pode-se dizer que a norma é de exceção e restritiva de direitos e, como tal, não admite interpretação extensiva. Para a premissa da relação aberta, volta-se ao argumento de que o Código Civil de 2002 adotou um sistema aberto, baseado em cláusulas gerais e conceitos indeterminados, na linha da teoria tridimensional do Direito e da ontognoseologia de Miguel Reale.

Entre as duas argumentações, para o presente ponto da matéria, este autor fica com a primeira. Excluir um herdeiro é algo extremamente grave, somente admitido em casos em que a lei expõe. Merecem transcrições, mais uma vez, as lições de Paulo Lôbo, destacado doutrinador contemporâneo, ao qual, agora, se filia: "As hipóteses legais constituem numerus clausus, ou seja, encerram em tipicidade fechada, não podendo outras condutas, por mais graves que sejam, fundamenta a exclusão do herdeiro. Assim é porque em nosso direito as restrições de direito são apenas as que a lei explicita, sendo vedada a interpretação extensiva" (Direito..., 2013, p. 175). (grifo nosso) (TARTUCE, 2019, p. 215).

Neste sentido, reitera o doutrinador que para a exclusão com base no inciso III, também deverá ser observada a sentença penal condenatória.

No mesmo sentido Cláudio Bueno caminha, trazendo ainda que o Tribunal de Justiça do Rio Grande Sul julgou pela manutenção da sentença que negou a exclusão do herdeiro por indignidade com base no inciso III, uma vez não comprovada de fato a sua existência, vejamos:

Exclusão de herdeiro. Indignidade. Art. 1.814, Ili, do CC. Ausência de comprovação. Impossibilidade da exclusão. Estando ausente comprovação de que o herdeiro, filho da falecida, a inibiu ou obstou de dispor de seus bens por ato de última vontade, não se pode impedi-lo de concorrer na herança de sua mãe. Demonstrado nos autos que todas as desavenças havidas se restringem ao pai e filho, geradas por disputas de ordem econômica e religiosa, não se vê autorizada a declaração de indignidade e consequente exclusão do herdeiro. Apelação desprovida. (TJRS, Ap. Cível n. 70.031.318.652, rei. Des. José Conrado de Souza Júnior, j. 14.10.2009). (GODOY, 2018).

Denota-se, que impera a necessidade de estar devidamente comprovado o delito cometido pelo suposto indigno, neste sentido, quando não há dúvidas do delito a indignidade impera de forma inquestionável, vejamos: 
Tendo o genro assassinado o sogro, não faz jus ao acervo patrimonial decorrente da abertura da sucessão. Mesmo quando do divórcio, e ainda que o regime do casamento seja o da comunhão de bens, não pode o varão receber a meação constituída dos bens percebidos por herança. (TJRS, Ap. Cível $n$. 70.005. 798.004, rei. Des. luiz Felipe Brasil Santos, j. 09.04.2003, v.m.)

O que legislador, dos artigos 1.814 e 1.815 ambos do Código Civil, quiseram e trouxeram autonomia ao magistrado para analisar as questões de indignidade, sendo de sua alçada tal pleito, conforme taxa o caput do artigo 1.815, porém, percebe-se o extremo cuidado em tais arguições de indignidade, entretanto os tribunais e inclusive o Tribunal do Rio Grande do Sul lá decidiu pela autonomia do processo civil em relação ao criminal, vejamos a jurisprudência trazido pelo doutrinador Cláudio Bueno: "Inexigível prévia condenação criminal para o ajuizamento da ação d e indignidade, despicienda a suspensão desta enquanto pende de julgamento o feito criminal. (TJRS, Al $n$. 70.002.423.044, rei. Des. Maria Berenice Dias, j. 30.05.2001)" (GODOY, 2018.)

Portanto, conclui-se, que o legislador, preocupou-se, com o princípio da presunção de inocência elencado na constituição, quando determina que a exclusão se dará somente por sentença, pois, no código civil não há a exigência de que seja uma sentença criminal, trazendo autonomia da esfera cível para a criminal, pois, a dilação probatória civil pode incluir fatos e provas criminais, incluindo uma sentença condenatória de primeiro grau criminal pode ser usado como elemento probatório na ação de indignidade, pois, por, ser uma ação autônoma a mesma preserva e garanti o direito ao contraditório e ampla defesa ao requerido gerando ao mesmo oportunidade de comprovar ou não sua inocência em dois processos.

\section{CONSIDERAÇÕES FINAIS}

O trabalho em questão abordou de forma transitiva e exploratória quanto ao tema que relata sobre os aspectos que levam o herdeiro a transgredir os delitos que concernem à sua exclusão como herdeiro das sucessões o tornando indigno para suceder a herança traçando os fundamentos de como se dá essa exclusão e se há a necessidade da condenação criminal ao que fere o princípio da presunção da inocência.

Inicialmente sustenta os parâmetros designados deste trabalho se define na área do direito de família e do direito civil, onde conceitua o âmbito familiar que é a base da sociedade e deve ser protegida pelo Estado, que são a união de pessoas determinadas pelo casamento, laço sanguíneo ou afetivo, conceitua-se a determinação da família baseando-se em obras, artigos e jurisprudências com menções à constituição federal brasileira dentre direito de família. 
Em seguida conceitua-se o casamento que é a base de formação da família e onde se determina os regimes de comunhão que são escolhidos durante a união, que assim refletem a determinação de herança e vocação hereditária que são abordadas também neste trabalho na parte de sucessões.

A sucessão nada mais é que o a transferência do patrimônio de alguém, depois de sua morte, ao herdeiro, em virtude de lei ou testamento, e conforme determina o artigo 1.829 do código civil, aos descendentes, ascendentes, cônjuge e colaterais.

A herança são os bens deixados pelo de cujus, ou falecido, essa herança só poderá ser transmitida aos determinados em lei como citado acima, ou os determinados em testamento.

Os herdeiros determinados podem receber a transmissão da devida herança desde que não seja indigno, ou seja, não cometa qualquer ato que venha a ter ferido a honra ou contra a vida do de cujus.

O herdeiro indigno é definido como aquele que comete ato de indignidade e para este o direito civil delimita-se como os excluídos da sucessão em seu artigo 1.814 do código civil, sendo esses autores, coautores ou partícipes de homicídio doloso, ou tentativa deste, contra a pessoa de cuja sucessão se tratar, seu cônjuge, companheiro, ascendente ou descendente, ou que houverem acusado caluniosamente em juízo o autor da herança ou incorrerem em crime contra a sua honra, ou de seu cônjuge ou companheiro, cabe ressaltar que ainda poderá ser excluído de testamento aquele que por violência ou meios fraudulentos, inibirem ou obstarem o autor da herança de dispor livremente de seus bens por ato de última vontade.

É apresentada de forma clara a aplicabilidade de tais contextos em fundamentos através de doutrinas e posicionamentos acerca do herdeiro Indigno, porém para que se conclua essa exclusão é necessária a ação declaratória de indignidade, após descoberto o delito que o torna indigno aquele herdeiro que cometeu tal ato, ficará impedido de receber a herança que the era de direito, desde que haja a declaração.

Tendo essa concepção podemos entender a qualificação do herdeiro e as hipóteses que o tornam indigno e ainda como essa indignidade procede em âmbito judicial, como por exemplo, neste contexto podemos perceber que a exclusão não ocorrerá por meio do processo penal e sim pelo processo civil, exigindo-se assim a existência de uma ação declaratória de indignidade, apesar da condenação no direito penal o direito civil consiste em uma independência da responsabilidade civil.

Conclui-se que não há necessidade de que haja uma sentença penal condenatória transitada em julgado para que seja declarada a indignidade, pois, trata-se de uma ação autônoma, onde é 
respeitado o devido processo legal, oferecendo ao herdeiro supostamente indigno o direito ao contraditório e ampla defesa, a dilação probatória oferece a oportunidade do mesmo poder provar na esfera civil sua inocência, uma vez que fosse exigida o transito em julgado da sentença penal, a indignidade poderia perdurar por prazo indeterminado, visto a morosidade de um processo penal e fase de recurso, podendo tal processo chegar ao pleno do STF, indo na contra mão do que o legislador buscou com a determinação de sentença civil para a declaração de indignidade, como já dito, e julgado pelo Tribunal de Justiça do Rio Grande do Sul, não é necessário o transito em julgado de uma sentença penal condenatória em relação ao disposto no artigo a.1.814 incisos I,II e III, do Código Civil. 


\section{REFERÊNCIAS}

AGÊNCIA SENADO. Descendentes de herdeiro indigno também podem ser proibidos de receber bens. Disponível em:

<http://www.ibdfam.org.br/noticias/na-midia/7794/Descen-

dentes+de+herdeiro+indigno+tamb\%C3\%A9m+podem+ser+proibidos+de+receber+bens >. Acesso em 14 mar.2019.

BRASIL, Código civil. Senado Federal, Vade Mecum. 22 ed. Saraiva São Paulo, 2017.

. Constituição da Republica Federativa do Brasil de 1988. Disponível em:

<http://www.planalto.gov.br/ccivil_03/constituicao/constituicaocompilado.htm> Acesso em 14 de mar.2019.

. Constituição da Republica Federativa do Brasil de 1988. Disponível em: <http://www.planalto.gov.br/ccivil_03/constituicao/constituicaocompilado.htm> Acesso em 16 de mar.2019.

. Lei no 13.532, de 7 de dezembro de 2017. Disponível em:

<http://www.planalto.gov.br/ccivil_03/_Ato2015-2018/2017/Lei/L13532.htm >. Acesso em: 14 jun 2020.

CAHALI, F. J., Curso Avançado de Direito Civil: Direito das Sucessões. Editora Revista dos Tribunais. São Paulo, 2003.

CONJUR. Legitimidade do MP para propor ação de exclusão do sucessor por indignidade. Disponível em:

<https://www.conjur.com.br/2018-jan-28/processo-familiar-legitimidade-mp acaoexclusaosucessorindignidade\#: :text=Quem\%20pode\%20propor\%20a\%20a\%C3\%A7C3\%A3o,0\% 20outro\%20recebe\%20toda\%20heran\%C3\%A7a.> Acesso em 04 jun.2020.

DIAS, Maria Berenice. Manual das Sucessões. 3. ed. São Paulo: Editora Revista dos Tribunais, 2013. DINIZ, Maria Helena. Curso de Direito Civil Brasileiro, volume 6 - Direito das Sucessões. São Paulo: Saraiva., 2014.

. Maria Helena. Curso De Direito Civil Brasileiro - Vol. 3 - 34a Ed. 2018.

. Maria Helena. Curso de Direito Civil Brasileiro: Direito das Sucessões, Vol. 6, 2018.

FOLHA Online. Andreas visita Suzane. Disponível em:

<https://www1.folha.uol.com.br/folha/cotidiano/ult95u62834.shtml> Acesso em 04 jun.2020.

FIUZA, Cezar. Direito Civil - Curso Completo. 12a ed. Belo Horizonte: Editora Del Rey, 2008.

GODOY, Cláudio Luiz Bueno de, Código Civil Comentado. 12ª ed. Barueri, ed. Manole 2018. 
GONÇALVES, Carlos Roberto, Direito civil brasileiro - direito de família. V6, 16 ed. Saraiva, 2020.

. Carlos Roberto, Direito civil brasileiro - direito de família. V6, 14 ed. Saraiva, 2017.

. Carlos Roberto, Direito civil brasileiro - direito de família. V7, 5 ed. Saraiva, 2011. HIRONAKA, Giselda M. F. N. Parte Especial do Direito das Sucessões. Vol. 20.2009

IBDFAM. Ministério Público agora tem legitimidade para pedir exclusão de herdeiro indigno. Disponível em: <https://ibdfam.jusbrasil.com.br/noticias/531562904/ministerio-publico-agora-temlegitimidade-para-pedir-exclusao-de-herdeiro-indigno>. Acesso em 14 mar.2019.

JUS.COM. BR. Princípios do contraditório e da ampla defesa. Disponível em:

< https://jus.com.br/artigos/49374/principios-do-contraditorio-e-da-ampla-defesa> . Acesso em 17 nov. 2020.

LISBOA, ROBERTO SENISE. Manual de Direito Civil - Vol. 5 - Direito de Família e Das Sucessões - 8a Ed. 2013.

MONTEIRO, W. B. Curso de Direito Civil Direito das Sucessões. Editora Saraiva, São Paulo, ed 35, v.6, 2003.

NADER, Paulo. Curso de Direito Civil. Vol. 5 - Direito de Família. 1. ed. Rio de Janeiro: Editora Forense, 2006.

NUCCl, Guilherme de Souza. Manual de direito penal . - 16. ed. - Rio de Janeiro: Forensse, 2020.

NOVAES, Felipe, BELLO Rodrigo. Manual de prática penal /. - 6. ed. - Rio de Janeiro: Forense; São Paulo: MÉTODO, 2020.

PEREIRA. Caio Mario da silva, Instituições de Direito Civil - Vol. V - Direito de Família: Volume 5,2017.

RODRIGUES, Silvio. Direito das Sucessões. 26. ed. Saraiva, 2003.

. Sílvio. Direito Civil. Vol. 6 - Direito de Família. 28. ed. São Paulo: ed. Saraiva, 2004. TARTUCE, Flávio. Direito Civil. Vol. 6 - Direito Das Sucessões, 12a ed. Rio de Janeiro, Ed. Forense, 2019.

VENOSA, Silvio de Salvo. Direito das Sucessões. 1. ed. Atlas S.A, 2001. 